by Shanchi Peng ${ }^{1,2}$, Loren E. Babcock ${ }^{3}$, Jingxun Zuo ${ }^{1,4}$, Xuejian Zhu ${ }^{1}$, Huanling Lin $^{1}$, Xianfeng Yang ${ }^{5}$, Yuping $\mathrm{Qi}^{1}$, Gabriella Bagnoli ${ }^{6}$, and Longwu Wang $^{7}$

\title{
Global Standard Stratotype-Section and Point (GSSP) for the Base of the Jiangshanian Stage (Cambrian: Furongian) at Duibian, Jiangshan, Zhejiang, Southeast China
}

\author{
1 Nanjing Institute of Geology and Palaeontology, Chinese Academy of Sciences, 39 East Beijing Road, Nanjing 210008, China. \\ E-mail: scpeng@nigpas.ac.cn; xjzhu@nigpas.ac.cn; ypqi@nigpas.ac.cn \\ 2 State Key Laboratory of Palaeobiology and Stratigraphy, Chinese Academy of Sciences, 39 East Beijing Road, Nanjing 210008, China \\ 3 School of Earth Sciences, The Ohio State University, 125 South Oval Mall, Columbus, Ohio 43210, USA, and Department of Geology, \\ Lund University, Sölvegatan 12, SE 22362 Lund, Sweden.E-mail: loren.babcock@geol.lu.se \\ 4 Henan Institute of Geological Survey, Zhengzhou 450007, China, zuojingxun@yahoo.com.cn \\ 5 Yunnan Province Key Lab in Palaeontology, Yunnan University, Kunming 650091, China. E-mail: yxf320@gmail.com \\ 6 Department of Earth Sciences, Pisa University, 56126 Pisa, Italy. E-mail: bagnoli@dst.unipi.it \\ 7 Geological Surveying Institution of Zhejiang Province, Xiaoshan, 311203, China. E-mail: zjhzwlw@126.com
}

The International Commission on Stratigraphy and the IUGS Executive Committee have recently approved a Global Standard Stratotype-section and Point (GSSP) defining the base of the second stage of the Furongian Series, Cambrian System. This stage is named the Jiangshanian Stage, after Jiangshan City, western Zhejiang Province, China, where the GSSP is located. The GSSP is exposed in a natural outcrop near Duibian Village. It is defined at the base of a limestone (wackestone) layer $108.12 \mathrm{~m}$ above the base of the Huayansi Formation in the Duibian B section, coinciding with the first appearance of the cosmopolitan agnostoid trilobite Agnostotes orientalis (base of the A. orientalis Zone). The GSSP is at a position of $28^{\circ} 48.977^{\prime} N$ latitude and $118^{\circ} 36.887^{\prime} E$ longitude. Secondary global markers at or near the base of the stage include the first appearance of the cosmopolitan polymerid trilobite Irvingella angustilimbata, which coincides with the FAD of the primary marker in the stratotype section, and near the end of a large positive carbon isotopic excursion (SPICE excursion). Faunal turnovers close to the base of the Jiangshanian Stage have been recognized as being at the base of the Iverian Stage in Australia, the Gonggrian Stage in Korea, and the Agnostotes orientalisIrvingella perfecta Zone in Siberia, and near the base of the Aksayan Stage in Kazakhstan, the Sunwaptan Stage in Laurentia, and the Parabolina brevispina Zone in Baltica.

\section{Introduction}

The purpose of this paper is to announce ratification of the Jiangshanian GSSP, the base of which coincides with the FAD of the cosmopolitan agnostoid trilobite Agnostotes orientalis. The GSSP for the base of the new stage, the Jiangshanian Stage (Figs. 1, 2, 6), is $108.12 \mathrm{~m}$ above the base of the Huayansi Formation in the Duibian B section, near Duibian Village, western Zhajiang, China (or $19.20 \mathrm{~m}$ above an arbitrary 0 point in the section) (Figs. 3, 5, 6). The base of the Jiangshanian Stage also coincides with the FAD of the cosmopolitan polymerid trilobite Irvingella angustilimbata in the Duibian B section. This point fulfills all of the geological and biostratigraphic requirements for a GSSP (see Remane et al., 1996). The section is easily accessible, and access for research is unrestricted. It is located on public land that has been under permanent protection of the government of Zhejiang Province since 1983, when the Duibian A section was proposed as a candidate for the global CambrianOrdovician boundary.

\section{Stratigraphic Rank of the Boundary}

The Jiangshanian Stage is the second stage of the Furongian Series (Figs. 1, 2, 7, 8). The base of the stage automatically defines the top of the Paibian Stage, and limits the Paibian to three globally or regionally recognized agnostoid trilobite zones, the Glyptagnostus reticulatus Zone, the Agnostus (= Innitagnostus) inexpectans Zone, and the Tomagnostella orientalis Zone. The boundary is a standard stage/age GSSP. 


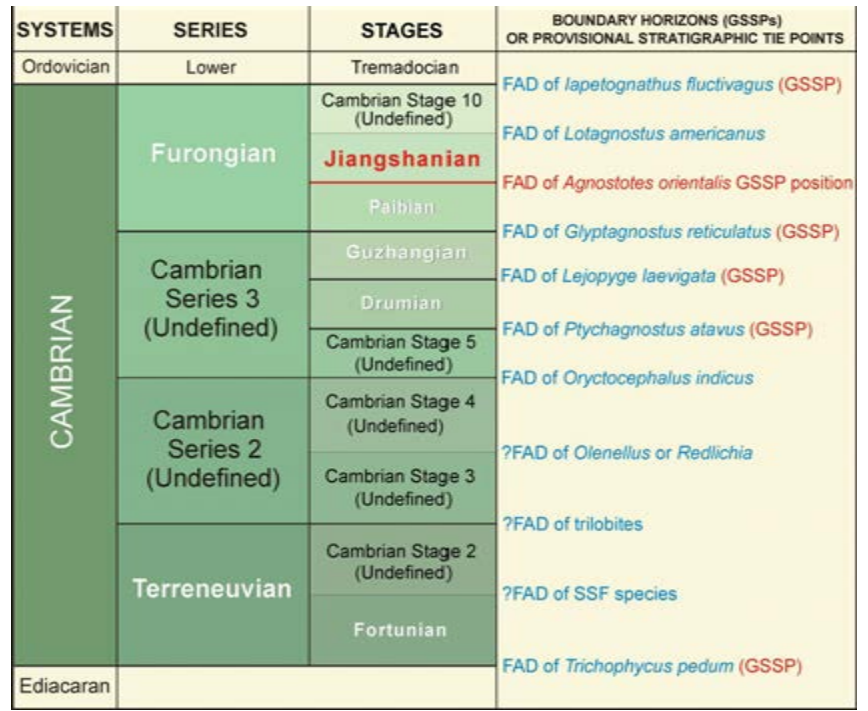

Figure 1. Chart showing working model for global chronostratigraphic subdivision of the Cambrian System, indicating lower boundary of the newly ratified Jiangshanian Stage (modified from Babcock et al., 2005).

\section{Geography and Physical Geology of the GSSP}

\section{Geographic Location}

The Duibian B section is exposed in natural outcrops situated at the base of Dadoushan Hill, northwest of Duibian Village, Jiangshan City, western Zhejiang Province (Peng et al., 2005, 2009a). The Duibian area is located within the district commonly called "Sanshan (Three Ranges) Region,” which straddles the border between Zhejiang and Jiangxi provinces. The district includes Jiangshan City and Changshan County, both of Zhejiang Province, and Yushan County of Jiangxi Province (Figs. 3, 4). The Duibian B section lies about 250 m south of the Duibian A section (Lu and Lin, 1989; Peng et al., 2005) at Duibian Village, and is about $10 \mathrm{~km}$ north of Jiangshan. Jiangshan is about $45 \mathrm{~km}$ from Quzhou, site of the nearest airport. Jiangshan is also about $310 \mathrm{~km}$, by expressway or by high speed railway, from Hangzhou, the capital of Zhejiang Province.

The Duibian A section contains strata extending from the Ediacaran to the Ordovician (Figs. 3, 7). It was originally measured by members of the Fuzhou Geological School (now the East China Institute of Technology), Jiangxi Province (in Lu and Lin, 1989) and subsequently documented in detail by Lu et al. $(1983,1984)$ and $\mathrm{Lu}$

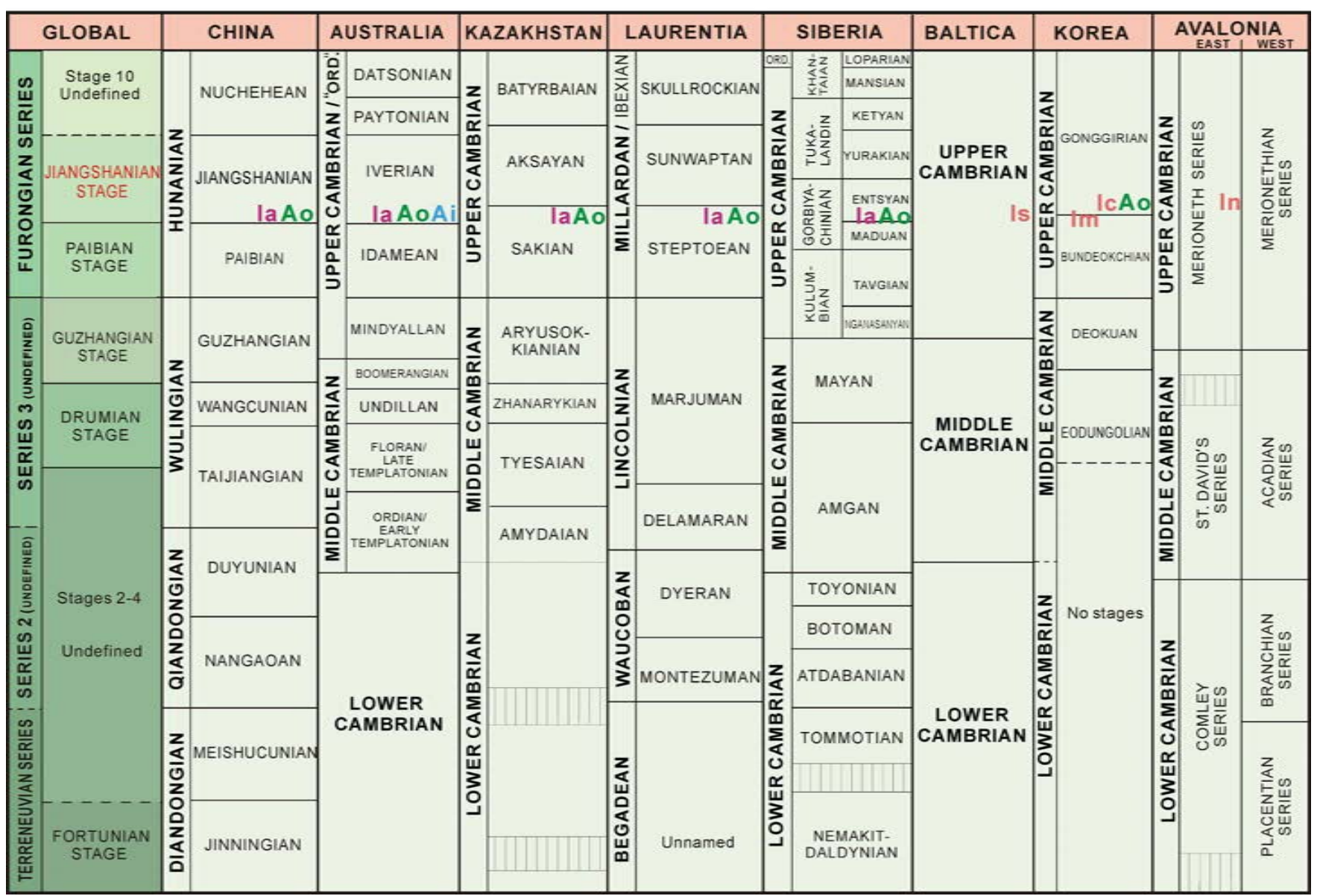

Figure 2. Correlation chart of the Cambrian showing the global chronostratigraphic stages compared to regional usage in major areas of the world (modified from Peng et al., 2004). The presence and horizon of Agnostotes in a region is indicated by symbols beginning with A: Agnostotes orientalis (Ao) and A. inconstans (Ai). The presence and horizon of Irvingella in a region is indicated by symbols beginning with I: Irvingella angustilimbata (Ia), I. megalops (Im), I. coreanica (Ic), I. sueccia (Is), and I. nuneatonensis (In). Chart compiled from numerous sources, summarized principally in Geyer and Shergold (2000) and Peng et al. (2004). 

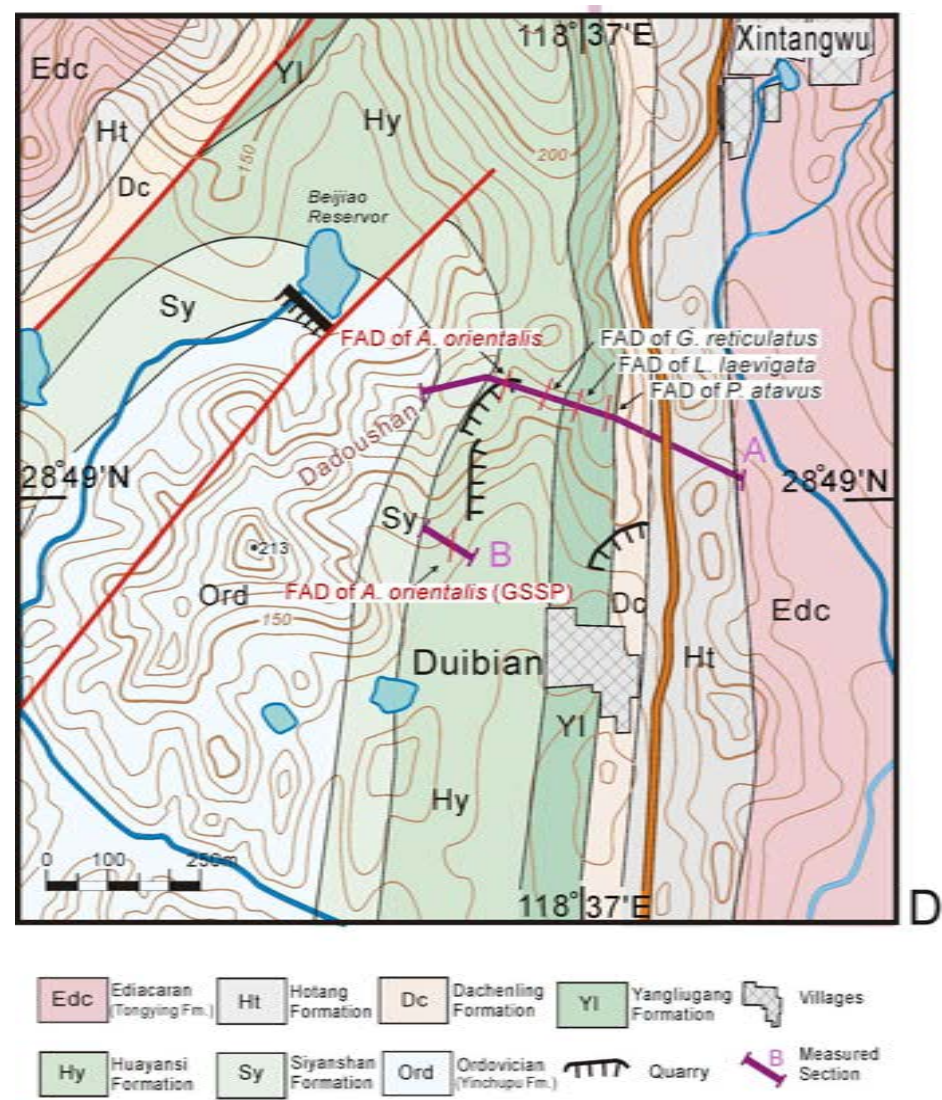
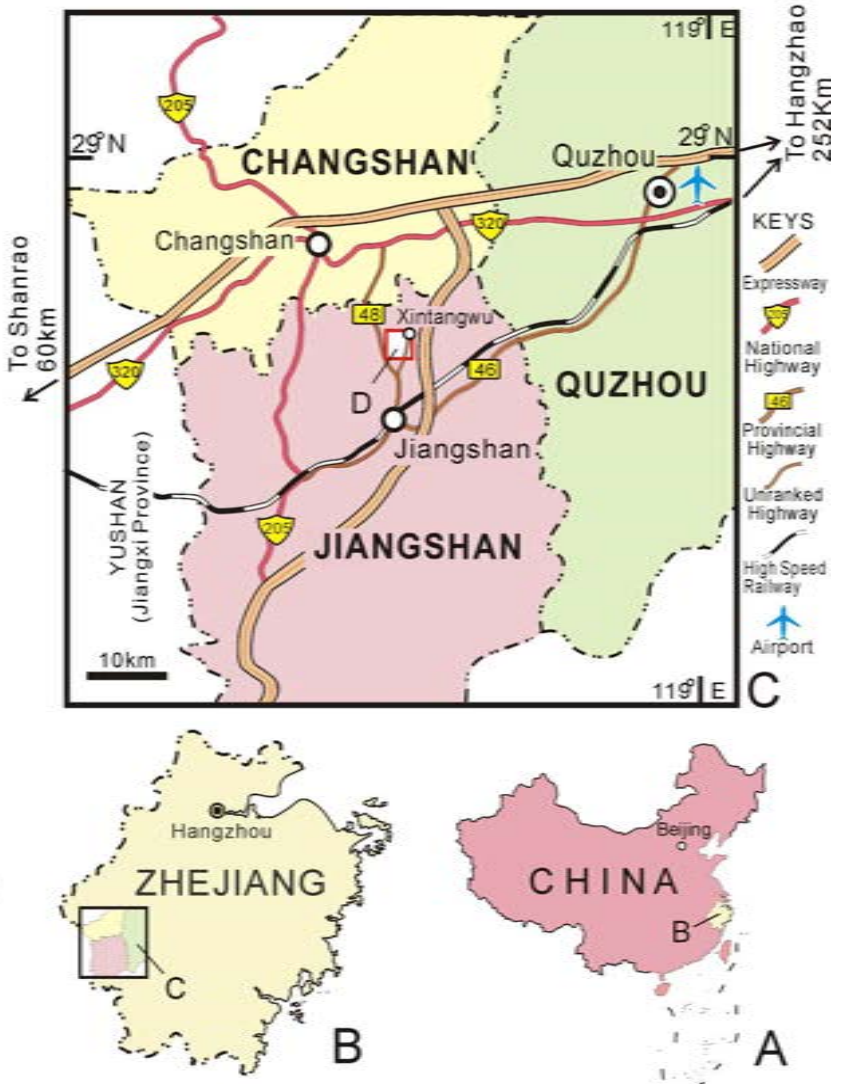

Figure 3. Topographic map of the Duibian area, Jiangshan, Zhejiang, China, showing the position of the Duibian A and B sections. Part $D$ of the figure is from topographic map H50-118-B (Surveying and Mapping Bureau of Zhejiang Province, 1961, scale 1:50000). Position of the Jiangshanian GSSP coincides with the FAD of Agnostotes orientalis in the Duibian B section.

and Lin (1989). The Duibian B section, first documented by Peng et al. (2005), is on the same limb of an unnamed syncline with the Duibian A section. It contains the upper part of the Huayansi Formation. The portion of the Duibian B section shown in Fig. 3 is the interval studied in greatest detail. The positions of both the Duibian A and B sections are on topographic map H50-118-B (Surveying and Mapping Bureau of Zhejiang Province, 1961, 1:50000 scale, Fig. 3D). The boundary stratotype for the base of the Jiangshanian Stage is the Duibian B section. The GSSP is exposed in outcrop at a position of $28^{\circ} 48.977^{\prime} \mathrm{N}$ latitude and $118^{\circ} 36.887^{\prime} \mathrm{E}$ longitude, and at an elevation of approximately $125 \mathrm{~m}$ above sea level.

\section{Geological setting}

The Sanshan Region is notable for its well exposed and richly fossiliferous lower Paleozoic strata. A GSSP for the base of the Darriwilian Stage (Ordovician) was erected at Huangnitang, Changshan County, Zhejiang Province (Mitchell et al., 1997), about $18 \mathrm{~km}$ northwest of Duibian (Fig. 4). Prior to final selection of the boundary stratotype, both the Duibian A section in Jiangshan and the Xiyanshan (Siyanshan) section in Changshan were among the candidate sections for the global Cambrian-Ordovician boundary (Lu et al., 1983, 1984). The Sanshan Region consists of an extensive series of folded and thrusted slices resulting from post-Devonian and post-Permian compressional tectonics that extend through parts of western Zhejiang and eastern Jiangxi provinces (Zhejiang Bureau of Geology and Mineral Resources, 1989; Jiangxi Bureau of Geology and Mineral Resources, 1984). The Duibian sections are situated on the east limb of a small syncline that constitutes one of the folds on the east limb of a much larger composite syncline ranging through eastern Jiangxi and western Zhejiang provinces (Fig. 4).

Cambrian strata of South China are assigned to three major depositional environments along a platform-to-basin transect (e.g., Pu and Ye, 1991; Peng and Robison, 2000; Peng and Babcock, 2001). Relatively shallow environments of the Yangtze (South China or Southwest China) Platform were flanked by deeper environments of the Jiangnan Slope Belt, and still deeper environments of the Jiangnan Basin. The GSSP occurs within the Huayansi Formation, which mainly consists of a thick succession of carbonate beds deposited in the outermost part of the Jiangnan Slope Belt, and adjacent to the Jiangnan Basin.

\section{Location of Level and Specific Point}

The first thin-bedded, dark gray limestone layer of the Huayansi Formation contains the earliest known specimens of the cosmopolitan agnostoid trilobite Agnostotes orientalis. The FAD of A. orientalis is $108.12 \mathrm{~m}$ above the base of the Huayansi Formation in the Duibian B section. The lowest known $A$. orientalis specimens co-occur with the cosmopolitan polymerid trilobite Irvingella angustilimbata.

Specimens of A. orientalis at its FAD position in the Duibian B section show the most primitive morphology exhibited in the species. The most notable microevolutionary changes in the species A. orientalis occur in the morphology of the frontal sulcus on the 

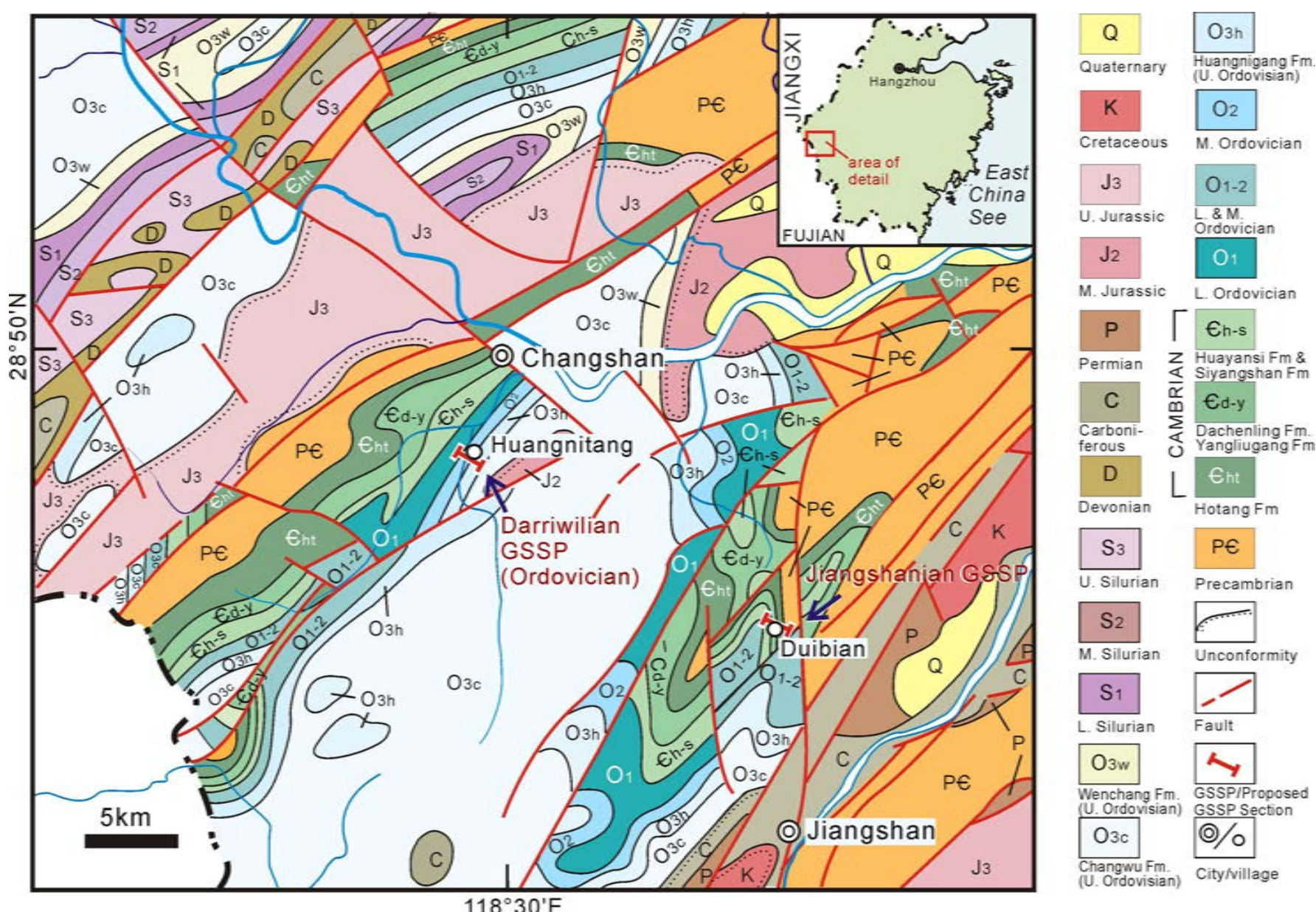

Figure 4. Map of part of western Zhejiang Province, China, showing location of the GSSP of the Jiangshanian Stage (Duibian B section, Duibian, Jiangshan). For reference, the location of the Huangnitang section, the GSSP for the Darriwilian Stage of the Middle Ordovician, is also indicated. Map modified from Zhejiang Bureau of Geology and Mineral Resources (1989).

anterior lobe of the glabella. In the primitive form, the frontal sulcus has a short notch (Fig. 9A, B). In younger and more advanced forms, the frontal sulcus becomes a long furrow that passes sagitally through the anterior lobe (Fig. 9C, D). As this change occurs, the width of the frontal sulcus increases progressively rearward to meet the transglabellar furrow and, as a result, the frontal sulcus separates the anterior lobe into a pair of ovate lobes. These striking morphologic changes can be used to gauge the relative stratigraphic occurrence of individual specimens of $A$. orientalis from any section in the world.

\section{Stratigraphic Completeness}

Detailed bed-by-bed correlation of Furongian strata through western Zhejiang, coupled with detailed biostratigraphy (Lu, 1964; Lu and Lin, 1981, 1983, 1989), sedimentology (Lu et al., 1974; Zuo, 2006), sequence stratigraphy (Zuo, 2006), and carbon isotope chemostratigraphy (Zuo, 2006; Figs. 6, 8), clearly demonstrates the stratigraphic continuity of the basal interval of the Jiangshanian Stage in the Duibian sections. Biostratigraphic studies within Zhejiang Province and globally demonstrate that the succession of trilobite species (e.g., Öpik, 1963, 1967; Lu and Lin, 1981, 1983, 1989; Ergaliev, 1980; Peng, 1990, 1992, 2000, 2003; Pratt, 1992; Ergaliev and Ergaliev, 2000, 2008, Geyer and Shergold, 2000; Varlamov et al., 2005; Peng et al., 2009a) and conodont species (e.g., Miller, 1981;
Wang, 1985; Dong et al., 2004; Miller et al., 2006) in the Duibian A and B sections is undisturbed. The Duibian B section lacks synsedimentary and tectonic disturbance at the GSSP boundary interval, although minor bedding-plane slippage, which is expected in an inclined succession of strata, especially when close to the axis of a syncline, occurs along some beds. Bedding plane slip surfaces do not appear to have resulted in any loss or repetition of stratigraphic thickness, and the biostratigraphic succession in the section is unaffected. There is no evidence of faulting resulting in either loss or repetition of section along the present exposure of the formation. Evidence of metamorphism and strong diagenetic alteration is absent.

\section{Thickness and Stratigraphic Extent}

In the Duibian B section (Figs. 5, 6), the upper part of the Huayansi Formation consists mainly of a succession of dark, thin-bedded limestones (wackestones) with thin shale interbeds; light-colored ribbon limestones (wackstones or packstones) are present in places. The upper part of the formation has a measured thickness of $50 \mathrm{~m}$. In the Duibian A section, the total thickness of the Huayansi Formation is $141.95 \mathrm{~m}$. Strata below the interval corresponding to the Duibian B section (i.e., the lower and middle Huayansi Formation) have occasional greenish-yellow shale beds less than $0.5 \mathrm{~m}$ thick. Another shale sequence occurs in an interval in the Lotagnostus americanus 

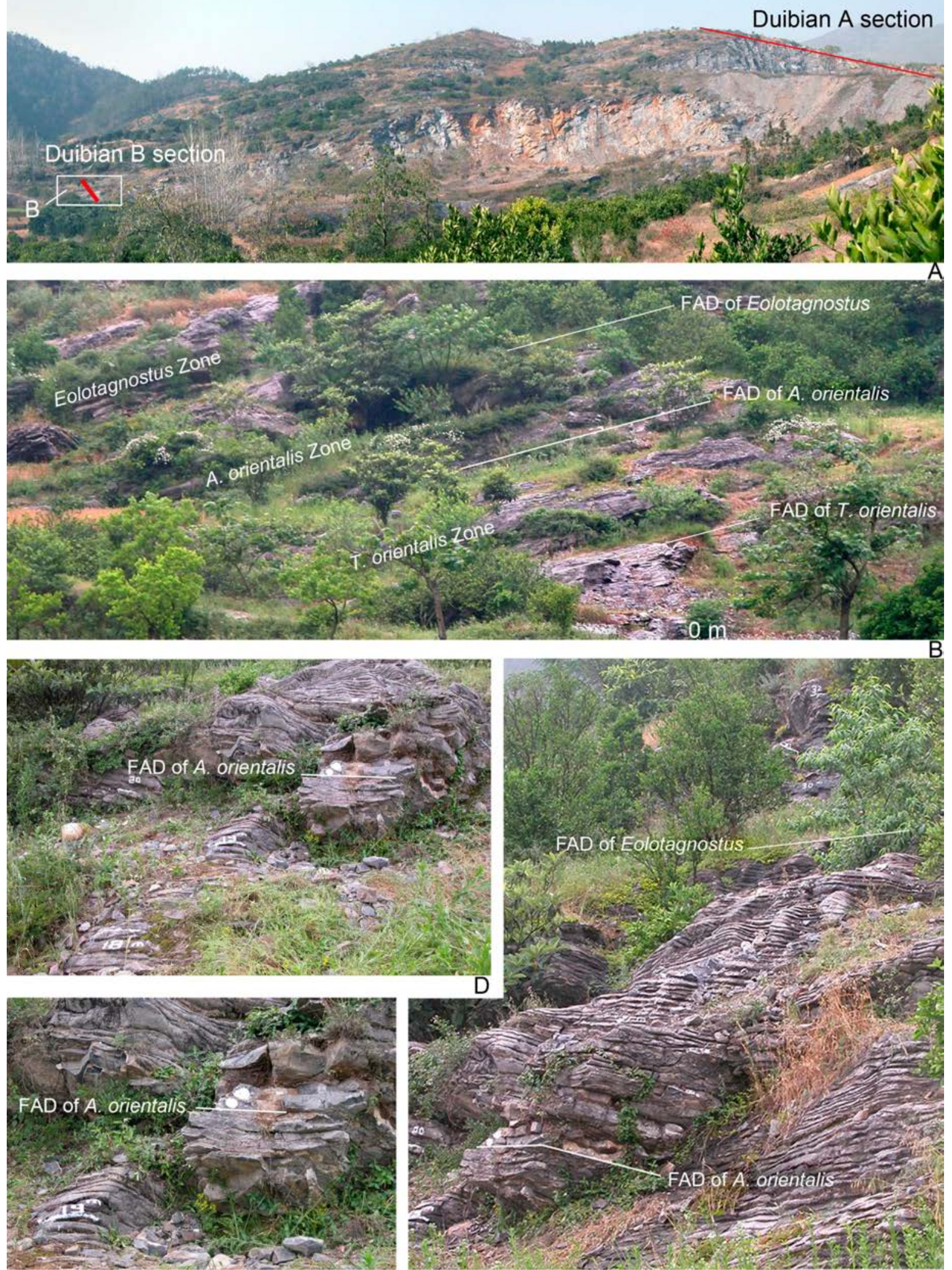

Figure 5. Exposure of the GSSP for the base of the Jiangshanian Stage (coinciding with the FAD of Agnostotes orientalis) in the Huayansi Formation, Duibian B section, Jiangshan, Zhejiang, China. Strata underlying the GSSP belong to the Paibian Stage. A, View of Dadoushan Hill with limestone quarries, northwest of Duibian Village, showing the location of Duibian A and Duibian B sections. B, Duibian B section. $C$, Interval between $19 \mathrm{~m}$ and $32 \mathrm{~m}$ above the arbitrary $0 \mathrm{~m}$ point in Duibian B section (107.4-120.4 $\mathrm{m}$ above the base of Huayansi Formation). D, E. Progressively closer views of the Duibian B section showing the FAD of A. orientalis, $108.12 \mathrm{~m}$ above the base of the Huayansi Formation (19.72 $\mathrm{m}$ above the arbitrary $0 \mathrm{~m}$ point). 
Zone (above the A. orientalis Zone). The shales are interpreted to have been deposited under basinal conditions, whereas the limestones represent a deep-water slope environment (Zuo, 2006).

The base of the Jiangshanian Stage occurs in a mostly monofacial succession of dark, fine-grained limestones. The point where $A$. orientalis first appears is in the lower part of an $8 \mathrm{~cm}$ thick layer of dark gray, thinly laminated wackestone, overlain by another $8 \mathrm{~cm}$ thick layer of thinly laminated, dark gray wackestone (beds with white painted circles on Fig. 5C-E). The basal contact of this bed in the Duibian B section extends laterally about $25 \mathrm{~m}$ along the section; it can be also traced northward to the Duibian A section, which is beyond the small bushes growing on the north side of the section.

\section{Provisions for Conservation, Protection, and Accessibility}

The exposure containing the GSSP is located on public land that has been under protection of the provincial government of Zhejiang Province since 1983. Because of the geologic importance of the Duibian sections, the sections are not subject to building, landscaping, or other destruction.

Access to the outcrop is essentially unrestricted in all seasons. Travel to Zhejiang is open to persons of all nationalities, and travel for scientific purposes is welcomed. Ordinary vehicles can be driven right to and parked beside the arbitrary 0 point of the Duibian B section. Almost no climbing is needed to examine and work on the stratotype section.

\section{Motivation for Selection of the Boundary Level and of the Stratotype Section}

\section{Principal Correlation Event (Marker) at GSSP Level}

The agnostoid trilobite Agnostotes orientals (Fig. 9A-G) has a global distribution and its first appearance has been acknowledged as one of the most favorable levels for a GSSP defining the base of a global Cambrian stage (e.g., Geyer and Shergold, 2000; Shergold and Geyer, 2001; Peng and Babcock, 2005b; Babcock et al., 2005; Peng et al., 2006). A position corresponding closely to the first appearance of A. orientalis is recognizable in strata of Gondwana, Laurentia, Kazakhstan, and Siberia (e.g., Kobayashi, 1935; Öpik, 1963; Lu, 1964; Lazarenko, 1966; Lu et al.,1965; Lu et al., 1974; Ergaliev, 1980; Lu and Lin, 1983, 1989; Peng, 1990, 1992; Pratt, 1992, Geyer and Shergold, 2000; Zhang, 2000; Pegel, 2000; Choi, 2004; Choi et al., 2004, 2005; Varlamov et al., 2005; Peng and Babcock, 2005b, Peng et al., 2005; 2006, 2009a; Ergaliev and Ergaliev, 2008; Lazarenko et al., 2008a, b; Varlamov and Rozova, 2009), and can be identified with reasonable precision using multiple lines of evidence.

Agnostoid trilobites provide the best and most precise tools for intercontinental correlation in the upper half of the Cambrian System (e.g., Robison, 1984; Peng and Robison, 2000); some intercontinentally distributed polymerids also provide fine stratigraphic resolution. In a number of regions, $A$. orientalis and the polymerid trilobite Irvingella co-occur (Lazarenko, 1966; Öpik, 1967; Peng, 1992; Pratt, 1992; Chatterton and Ludvigsen, 1998; Hong and Choi, 2003; Choi et al., 2004, 2005; Varlamov et al., 2005). Irvingella has a wide paleogeographic distribution (Geyer and Shergold, 2000), allowing precise or close correlation into Australia, Baltica, Avalonia, eastern and western Laurentia, Argentina, and probably Antarctica. A. orientalis, or co-occurring Agnostotes and Irvingella, have been used as zonal guide fossils in South China, northeastern and northwestern Siberia, and South Korea. Palmer (1965) and Hong and Choi (2003) recognized a distinct evolutionary series among species of Irvingella that can be used to help constrain stratigraphic position.

In South China and Canada, the primitive form of $A$. orientalis makes its first appearance at a level coinciding with the FAD of Irvingella angustilimbata (Peng, 1992; Pratt, 1992). This level defines the base of the Jiangshanian Stage in South China and the base of the Proceratopyge rectispinata Zone in the Mackenzie Mountains. It lies somewhat below the lower boundary of the Sunwaptan Stage of Laurentian regional usage, which is defined at the base of the Irvingella major Zone (Chatterton and Ludvigsen, 1998). Everywhere that Irvingella major occurs in strata it is always higher than $I$. angustilimbata. The stratigraphic position and its modified morphology suggest that I. major is an advanced species of Irvingella, one that was derived from I. angustilimbata or a similar relatively primitive species. The first appearance of $A$. orientalis corresponds closely to the base of the Iverian Stage in Australia (Shergold, 1993), the base of the Pseudagnostus (P.) vastulus-Irvingella tropica Zone in Kazakhstan (Ergaliev, 1980), and near the base of the "Entsyan horizon” of the Gorbiyachinian Stage (Rozova, 1963; Varlamov et al., 2005) or the base of the Mokuteian regional stage (Varlamov and Rozova, 2009) in Siberia. In South Korea, an advanced form of $A$. orientalis was recorded in association with Irvingella coreanicus and is succeeded by I. major. It succeeds I. megalops, which is comparable to I. angustilimbata and occurs in the underlying Eochuangia hana Zone. This led Hong and Choi (2003) to correlate the base of the $E$. hana Zone, or the base of the Gonggairian Stage of South Korean regional usage, to the GSSP level. Hong and Choi (2003), Choi (2004) and Choi et al. (2004; 2005) also suggested that Irvingella nuneatonensis from England (Rushton, 1967, 1983) occurs nearly at the same level as, or slightly above, the Korean A. orientalis Zone. In Sweden, A. orientalis is not known, but the level corresponding to its first appearance may be at or close to the FAD of Irvingella suecica, which is presumed (Terfelt et al., 2008, 2011) to be in the Parabolina brevispina Zone (polymerid trilobite zonation) and lowermost Pseudagnostus cyclopyge Zone (agnostoid zonation).

Stratigraphically, the first appearance of primitive Agnostotes orientalis always succeeds the first appearance of Tomagnostella orientalis in South China (Peng, 1992; Choi et al., 2004). Up-section, specimens of $A$. orientalis having the primitive morphology are replaced by ones having more advanced morphologies (Peng, 1992; Peng et al., 2009a; herein). A similar succession, in which primitive A. orientalis specimens become replaced by advanced ones, is also observable in the Chopko and Khos-Nelege River sections, Siberia (Varlamov et al., 2005; Lazarenko et al., 2008a, b). Species of Agnostotes always succeed the first appearance of the widespread polymerid Corynexochus plumula, which is the eponymous guide fossil for the C. plumula Zone. The C. plumula Zone, in turn, lies above the Erixanium rectangularis Zone in stratigraphic successions of Australia and South China (Öpik, 1967; Peng, 1992; Duan, 2003). The first appearances of both E. rectangularis and C. plumula always succeed the first appearances of the cosmopolitan agnostoid trilobites Agnostus inexpectans and Glyptagnostus reticulatus. It is desirable 

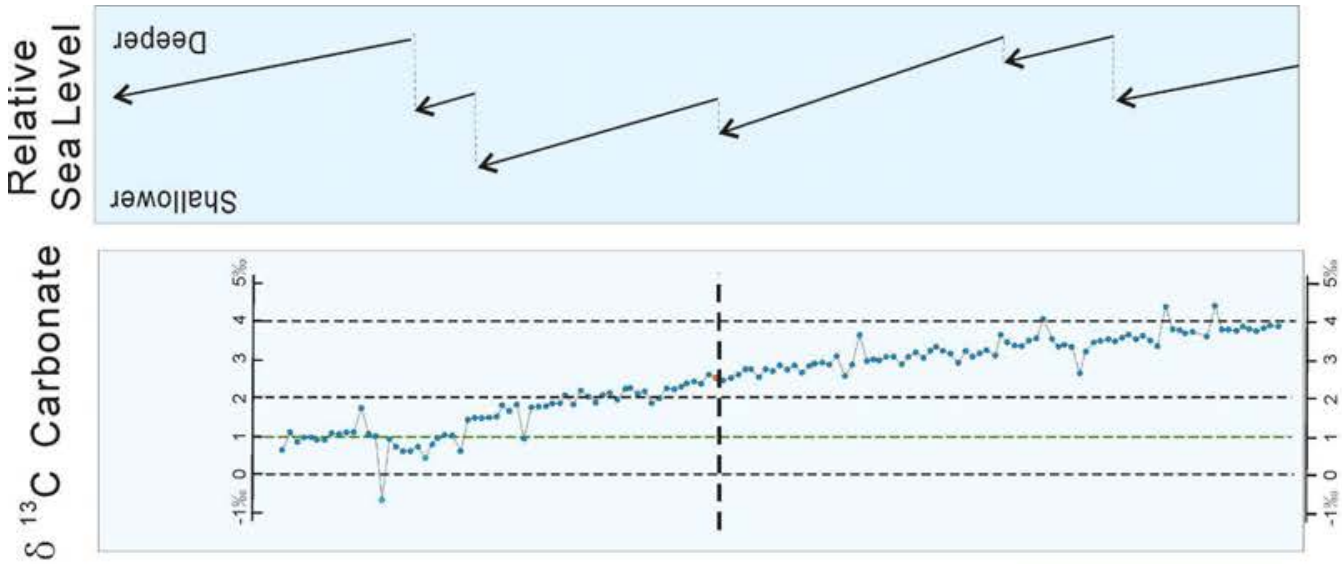

- ds smisoubepnasd |

- nou ds smisoubeorn

- joleu ellaбuinu

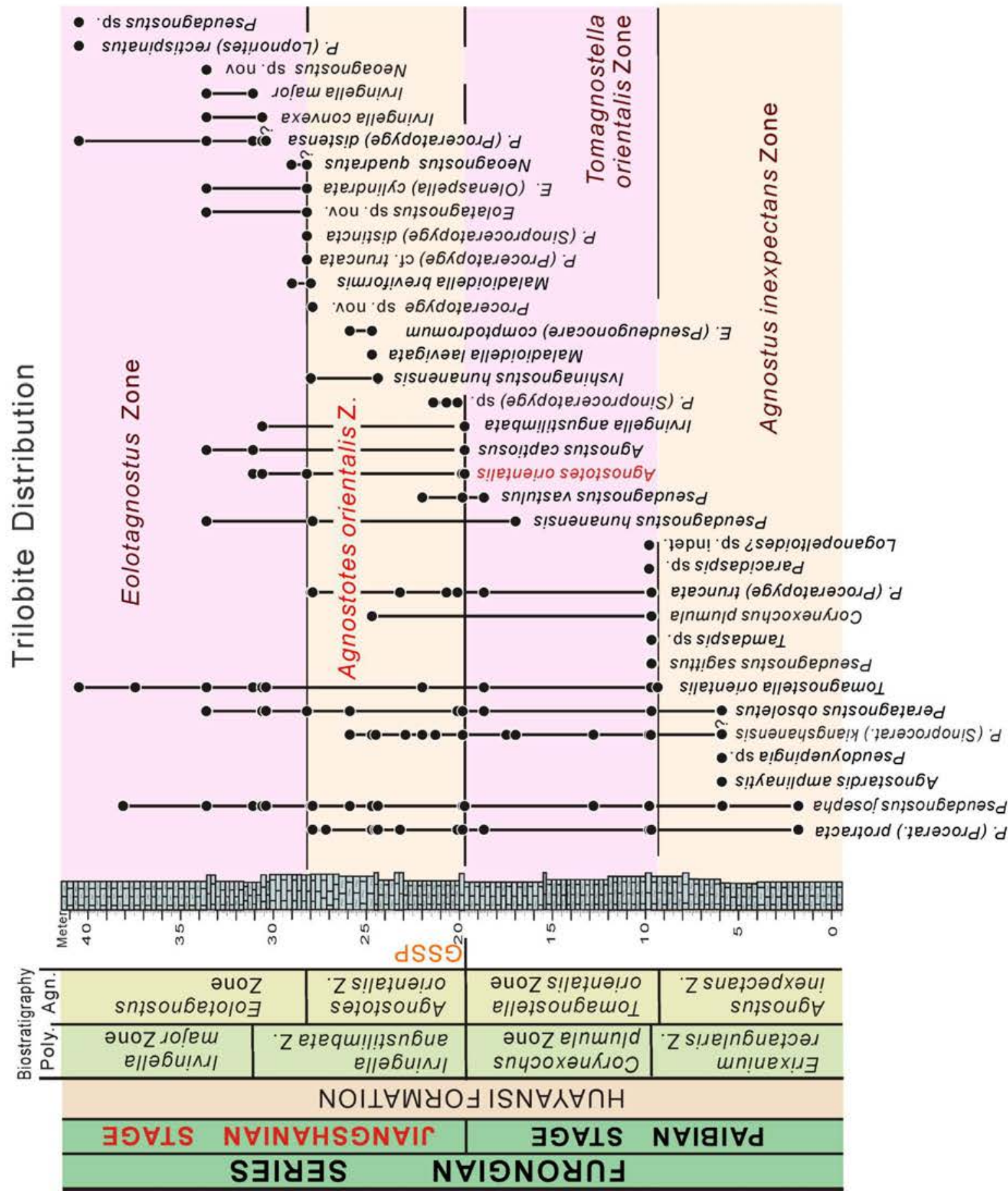

ะี 


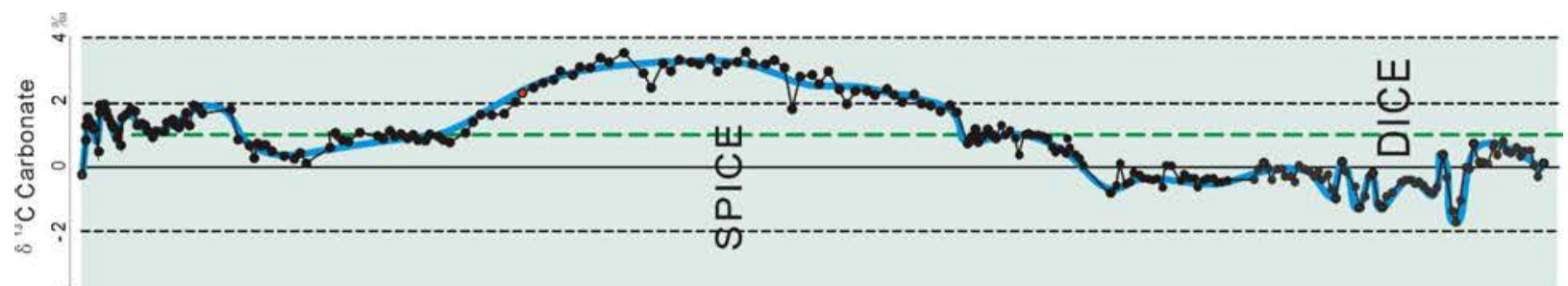

ఏे

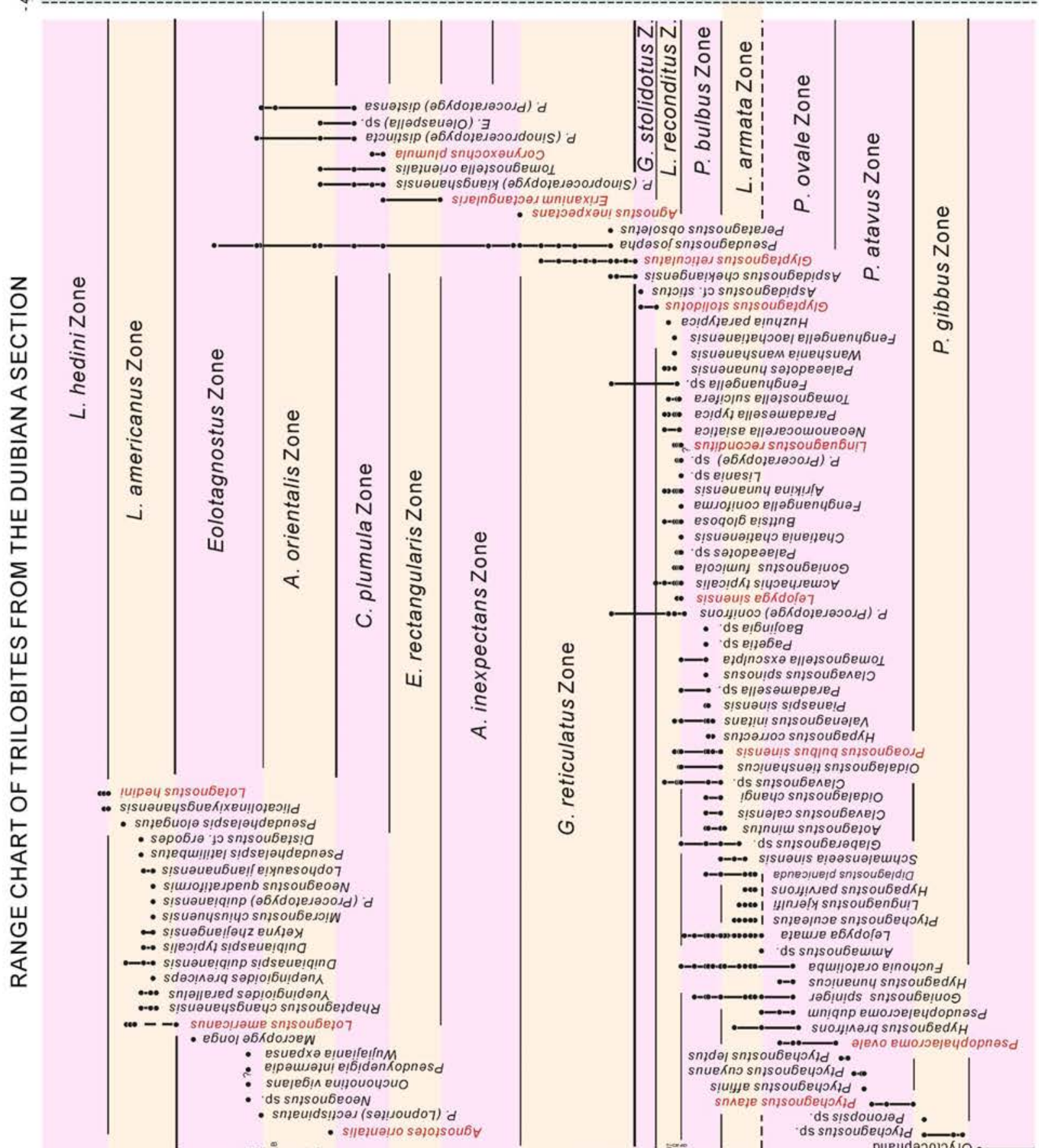

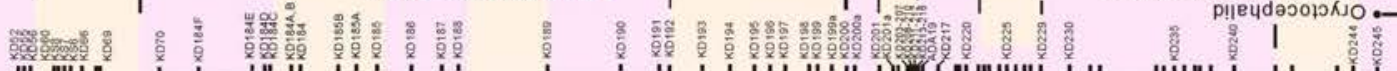

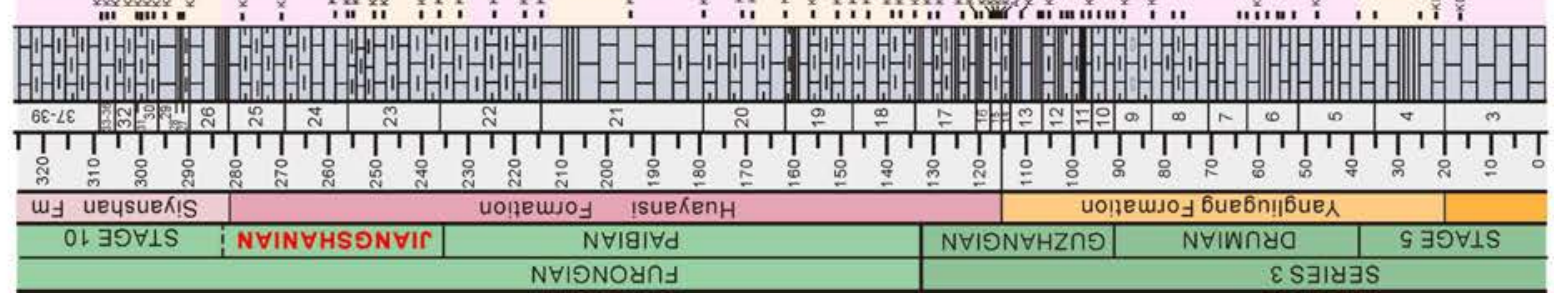


to select the position of a GSSP in a section showing a complete succession from the G. reticulatus Zone (or the A. inexpectans Zone if recognized regionally) through the $A$. orientalis Zone. Selection of the FAD of $A$. orientalis as the primary correlation tool for the base of the Jiangshanian Stage ensures that the boundary will fall within a stratigraphic interval bearing both agnostoid trilobites, many of which are phylogenetically related, and species of the polymerid trilobite Irvingella. Together, the narrow stratigraphic range of $A$. orientalis (if both the primitive and advanced forms are present), and the stratigraphic disappearance of both A. inexpectans and G. reticulatus, allows the boundary to be tightly constrained.

\section{Stratotype Section}

The lowest observed occurrence of A. orientalis, as recorded by Lu and Lin (1989), in the Duibian A section occurs in the upper part of the Huayansi Formation, $116.6 \mathrm{~m}$ (collection AD185) above the base of the formation (Fig. 7). Recent detailed work shows that the faunal elements present at this level are identical with those from collection DB 28.2 (28.2 m above the arbitrary 0 point) in the Duibian $\mathrm{B}$ section. The lowest occurrence of $A$. orientalis in the Duibian B section is in collection DB19.72 (19.72 $\mathrm{m}$ above the 0 point). This suggests that the FAD of $A$. orientalis should be $108.12 \mathrm{~m}$ above the base of the Huayansi Formation in the Duibian A section. Agnostoid trilobite zonation of the Huayansi Formation in the Duibian B section reveals a complete, tectonically undisturbed, marine succession through the upper part of the Paibian Stage (the A. inexpectans and Tomagnostella orientalis zones) into the GSSP level (coinciding with the base of the A. orientalis Zone), through the Eolotagnostus Zone of the Jiangshanian Stage. Strata correlated with these zones are also recognized in the Duibian A section and elsewhere in South China.

The stratotype of the Jiangshanian Stage reveals a succession of widespread agnostoid trilobite assemblages. Some of the species present are phylogenetically related pseudagnostid and agnostid species. Successive stratigraphic levels show a succession with the FAD of Agnostus inexpectans (ranging upward from $53.55 \mathrm{~m}$ above the base of the Huayansi Formation; upper part of the Glyptagnostus reticulatus Zone), the FAD of Tomagnostella orientalis (98.1 m above the base of the formation), the FAD of Agnostotes orientalis (108.12 $\mathrm{m}$, coinciding with the base of the Jiangshanian Stage), the FAD of Ivshinagnostus hunanensis (112.8.4 m), the FAD of Eolotagnostus sp. nov., and possibly specimens of the advanced form of $A$. orientalis (116.6 m). Definite advanced specimens of A. orientalis occur at 119 $m$ above the base of the Huayansi Formation. For polymerid trilobites, the stratigraphic succession includes assemblages bearing Erixanium rectangularis, followed by Corynexochus plumula, Irvingella angustilimbata, and Irvingella major. The FAD of I. angustilimbata coincides with the FAD of Agnostotes orientalis, and this provides a reliable secondary tool for defining the base of the Jiangshanian Stage. Besides the two guide species of Irvingella, a third species of Irvingella, I. convexa, occurs in succession above I. angustilimbata but below I. major in the Duibian B section.

The most common polymerid trilobites in the Duibian B section are ceratopygids (Proceratopyge, Tamdaspis, Sinoproceratopyge). Among them is Proceratopyge (Sinoproceratopyge) kiangshanensis, which is commonly used as a guide fossil in South China ( $\mathrm{Lu}$ and Lin, 1989; Peng, 1992). The general morphology of Proceratopyge (Sinoproceratopyge) distincta suggests that it possibly gave rise to early species of the Hedinaspis lineage (e.g., Hedinaspis
(=Asiocephalus) sulcatus, $H$. canadensis), and one of these may in turn have given rise to Hedinaspis regalis. In the bed containing the lowest $A$. orientalis in the Duibian B section (108.12 m), the guide species is rare. However, the species is common to abundant in the upper part of the section (119 $\mathrm{m}$ and $119.5 \mathrm{~m}$ ), where it is represented by the advanced forms.

Observed ranges of trilobites across the stratigraphic interval containing the GSSP are summarized in Figure 6. As mentioned above, besides $A$. orientalis, a number of other guide fossils, important for intercontinental or interregional correlation, help to constrain the boundary position.

Conodonts (Figs. 11, 12) are relatively rare in most intervals of the Duibian sections (Lu et al., 1984; herein). In a few layers, however, they occur in abundance and are rather diverse. A conodont association with 10 species has been recorded in the Duibian B section from a short interval about $10 \mathrm{~m}$ above the boundary. Components of this association are tentatively assigned to the Westergaardodina cf. calix - Prooneotodus rotundatus Zone of Dong et al. (2004). Samples taken for conodonts close to the GSSP level were unproductive.

\section{Demonstration of Regional and Global Correlation}

A position at or closely corresponding to the FAD of A. orientalis in the Duibian $B$ section is one of the most easily recognizable horizons on a global scale in the Cambrian (e.g., Geyer and Shergold, 2000; Peng and Babcock, 2005b; Babcock et al., 2005; Fig. 2), in part because the level is marked by the joint first appearances of $A$. orientalis and I. angustilimbata. Suitability of the FAD of A. orientalis for marking a global stage boundary has been summarized principally by Geyer and Shergold (2000), Peng and Babcock (2005a, b), and Peng et al. (2005, 2006, 2009a). Key correlation tools are described in the following subsections.

\section{Agnostoid trilobite biostratigraphy}

As mentioned above, $A$. orientalis has been recognized worldwide and used as a zonal guide fossil independently or jointly with species of either Irvingella or P. (Sinoproceratopyge) in deposits of Gondwana and Siberia (e.g., Lu and Lin, 1981, 1983, 1989; Öpik, 1963, 1967; Ergaliev 1980; Eragliev and Ergaliev, 2000; Geyer and Shergold, 2000; Shergold and Geyer, 2001; Peng, 1992; Hong and Choi, 2003; Choi, 2004; Choi et al., 2004; 2005; Varlamov et al., 2005; Varlamov and Rozova, 2009). An agnostoid trilobite-based biostratigraphy, one that is distinct from polymerid trilobite-based biostratigraphy, has been proposed for the middle and upper parts of the Furongian Series, based largely on the succession in the Duibian B section. The guide fossils in the two lower zones are also widely distributed. The agnostoid trilobite faunas of the Duibian B section allow a close correlation of the horizon containing the GSSP into Gondwana, Kazakhstan, Laurentia, Siberia, Baltica, and Avalonia.

\section{Polymerid trilobite biostratigraphy}

A new polymerid trilobite biostratigraphy that parallels the agnostoid trilobite biostratigraphy is proposed for the middle and upper Furongian in the Duibian sections. Four zones are recognized. In ascending order, they are the Erixanium rectangularis Zone, the 


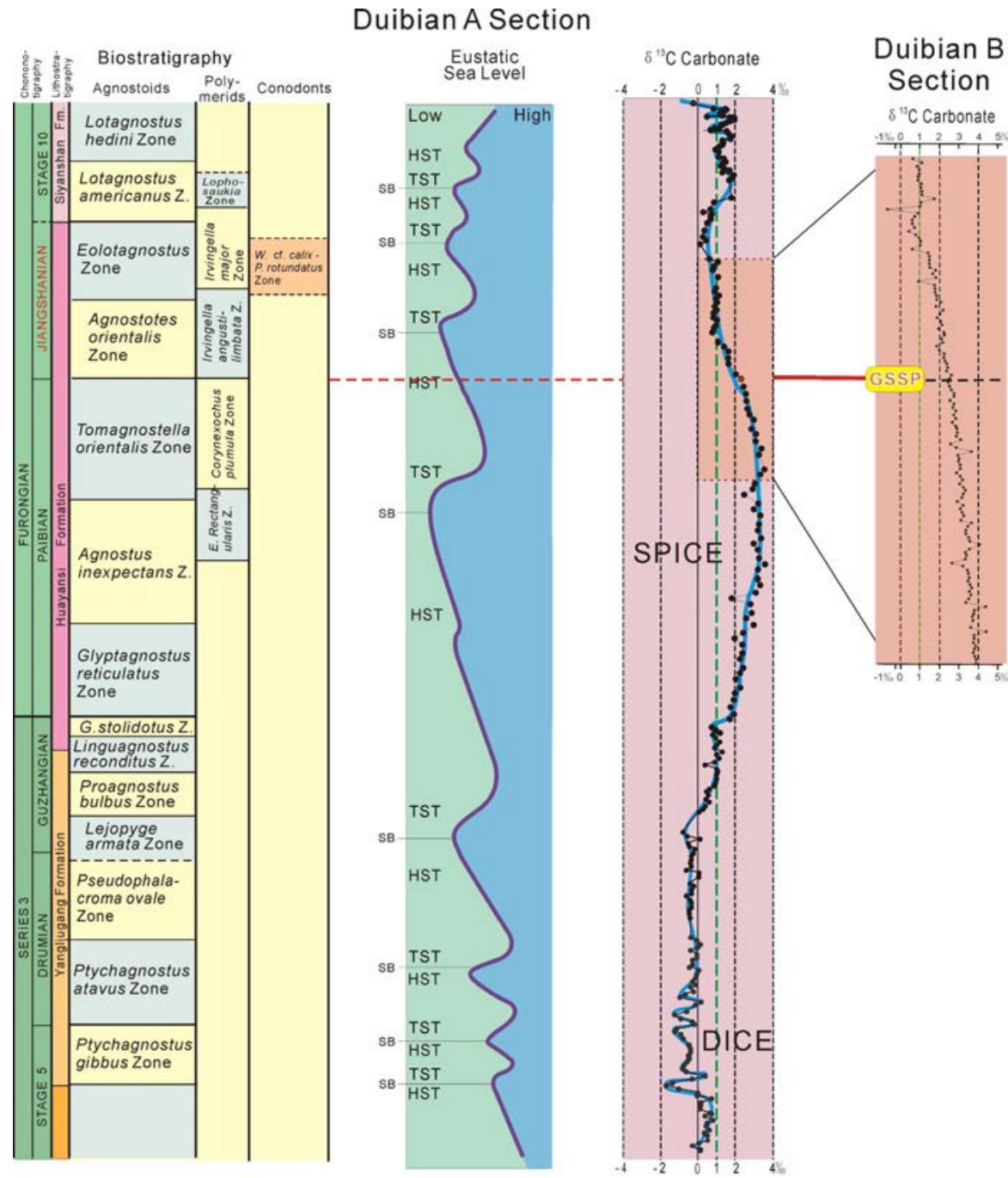

Figure 8. Summary of primary and secondary stratigraphic indicators for the base of the Jiangshanian Stage of the Cambrian System. Major stratigraphic tools used to constrain the GSSP of the stage are the zonation of agnostoid and polymerid trilobites (Lu and Lin, 1981; 1983, 1989; Peng et al., 2006; 2009a), the occurrences of conodonts (Peng et al., 2009a), carbon isotope chemostratigraphy (records from the Duibian A and Duibian B sections from Zuo, 2006), and sequence stratigraphy (Zuo, 2006), all of which have applied in the Duibian B section.

Corynexochus plumula Zone, the Irvingella angustilimbata Zone, and the Irvingella major Zone (Figs. 6, 8). The base of the A. orientalis Zone coincides with the base of the I. angustilimbata Zone. I. angustilimbata has been recognized in the upper part of the Elvinia Zone in Laurientia (Pratt, 1992), the Irvingella tropica [= I. angustilimbata] Zone in Australia (Öpik, 1963; Geyer and Shergold, 2000), the Agnostotes clavata [=A. orientalis] -Irvingella angustilimbata Zone in Siberia (Varlamov and Rozova, 2009), and the Pseudagnostus (P.) vastulus-Irvingella tropica $[=I$. angustilimbata] Assemblage-zone in Kazakhstan (Ergaliev and Ergaliev, 2008). Similar preglabellar field-bearing species of Irvingella, assigned to I. megalops, have been recognized at the base of the Eochuangia hana Zone in South Korea (Hong and Choi, 2003).

\section{Conodont biostratigraphy}

The interval from $29.12 \mathrm{~m}$ to $31.5 \mathrm{~m}$ above the 0 point (i.e.,117.52 m to 119.9 m above the base of the Huayansi Formation), here assigned to the lowermost part of the Eolotagnostus trilobite zone, yield a conodont fauna with 10 species including, among others, Coelocerodontus bicostatus, Prooneotodus gallatini, and Prooneotodus rotundatus. These taxa, even though they range higher, possibly indicate the Westergaardodina cf. calix - Prooneotodus rotundatus Zone established by Dong et al. (2004) for South China. This zone is characterized by the abundance of Prooneotodus and is broadly equivalent to the $W$. aff. fossa $-P$. rotundatus Zone established by An (1987) for North China. Other taxa present in the Duibian B section are either long ranging or left in open nomenclature due to poor preservation. Some specimens could be early representatives of Proconodontus, but this assignment requires further investigation.

\section{Chemostratigraphy}

The FAD of $A$. orientalis occurs within the upper part of the SPICE excursion, near the end of a long, monotonic decline of the $\delta^{13} \mathrm{C}$ excursion (Figs. 6-8). The underlying Paibian Stage is characterized by a long positive shift with a maximum value of $4.2 \%$ being reached in the middle of the Erixaniaum rectangularis Zone (Figs. 6, 7). The peak interval occurs in the upper part of the E. rectangularis Zone and lower part of the Corynexochus plumula Zone, where positive $\delta^{13} \mathrm{C}$ values vary between 3 and $4 \%$.

The FAD of $A$. orientalis occurs just below the peak of a long monotonic shift in ${ }^{87} \mathrm{Sr} /{ }^{86} \mathrm{Sr}$ toward the maximum value $(0.7082)$ reached in the Cambrian (Peng et al., 2012), although Sr isotope values have not been recorded from the Duibian B section. The peak value closely coincides with the sharp return to near0 values of $\delta^{13} \mathrm{C}$ at the end of the SPICE excursion and the extinction associated with the Pterocephalid Biomere in Laurentia.

\section{Sequence stratigraphy}

Work in the Duibian sections shows that the base of the $A$. orientalis Zone is associated with the late part of a long regressive event whose inception is recorded in the lower part of the $A$. inexpectans Zone (Figs. 6, 8). Overall, the Yangliugang, Huayansi, and Siyangshan formations in the Duibian A section are inferred to have been deposited during eight third-order cycles (Zuo, 2006), which together form a second-order cycle. Superimposed on these long-term cycles are a series of smaller scale transgressive-regressive cycles. A comparable sequence stratigraphy with eight third-order cycles within a larger second-order cycle has been recognized from a basically equivalent stratigraphic interval in Guizhou Province, China (Mei et al., 2007). In the Duibian B section, the FAD of A. orientalis 


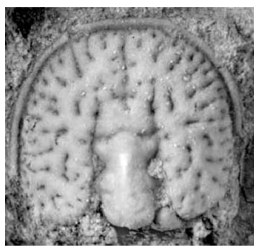

A
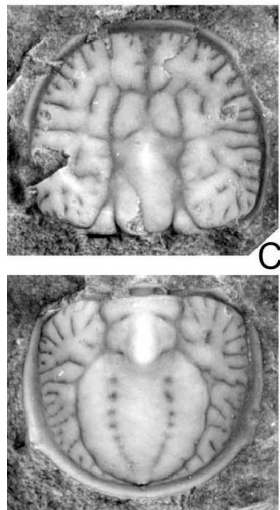

E

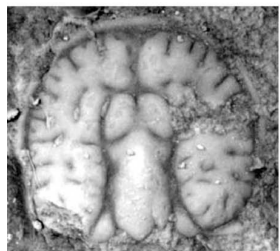

G

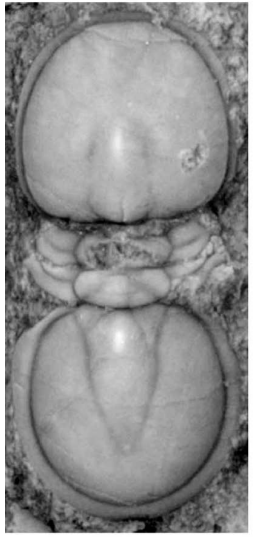

S

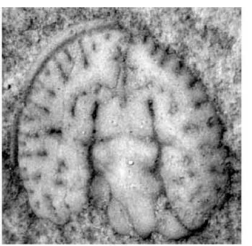

B
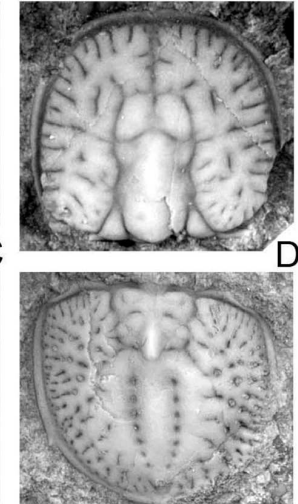

F

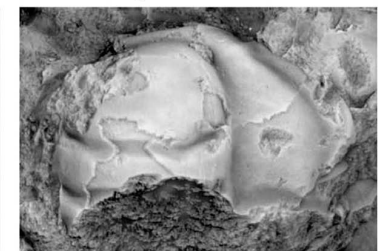

O

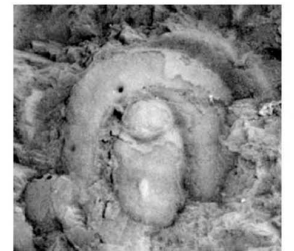

T

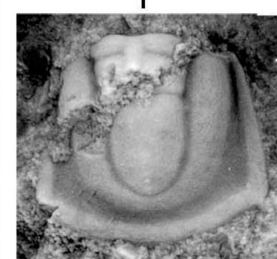

U

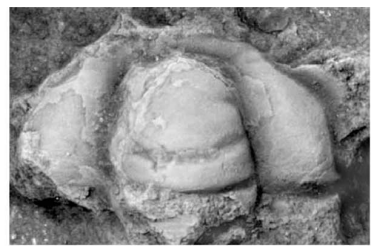

H

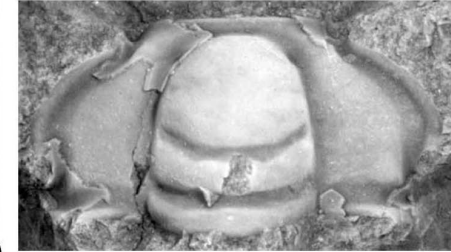

K

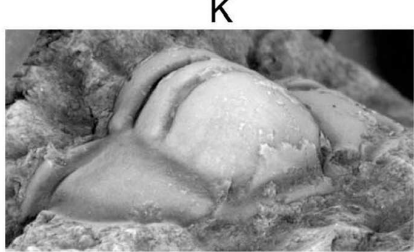

M

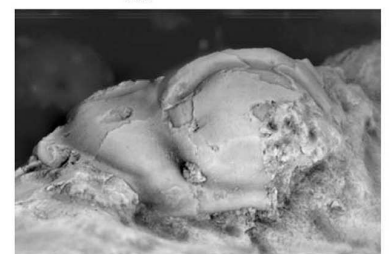

P

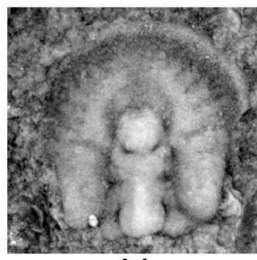

$\mathrm{V}$

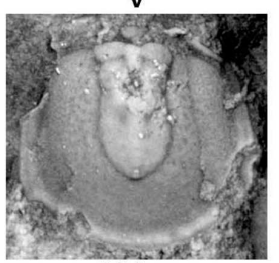

W

I

X
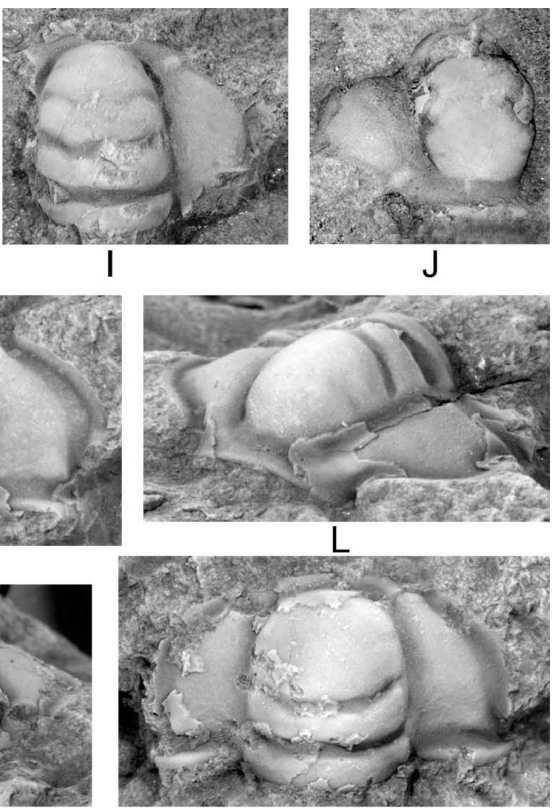

N

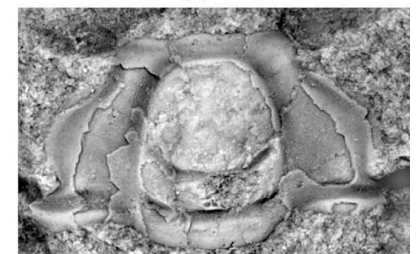

Q
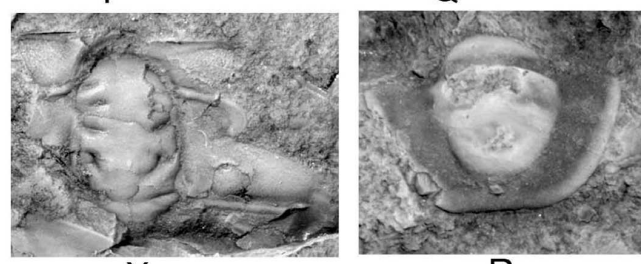

R
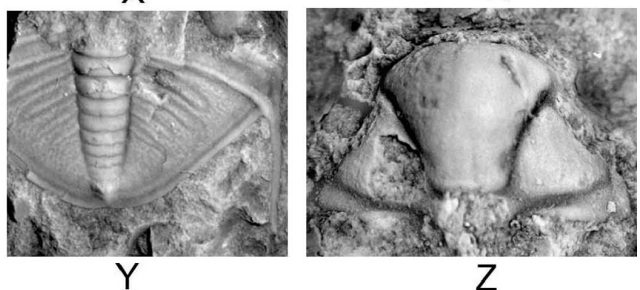

Z

Figure 9. Key trilobite species used for recognition of the base of the Jiangshanian Stage. Numbers with the prefix DB (for Duibian section) indicate collecting horizons in meters above the arbitrary $0 \mathrm{~m}$ point. Unless stated otherwise, all are dorsal views. A-G, Agnostotes orientalis (Kobayashi, 1935), a series of primitive and derived forms. A, B, two cephala, DB19.72, $108.12 \mathrm{~m}$ above the base of Huayansi Formation, $\times 6, \times 7.5$; note that the frontal sulcus has a short notch; $C-F$, two cephala $(C, D)$ and two pygidia $(E, F), D B 30.6,119 \mathrm{~m}$ above the base of Huayansi Formation; note that the frontal sulcus on the cephalon extends rearward into the transglabellar furrow and divides the anterior lobe of the glabella into a pair of ovate lobes, $\times 5.4, \times 6, \times 5, \times 4.6$; G, cephalon, DB31.1, 119.5 m above the base of Huayansi Formation, $\times 9$; note that the frontal sulcus in this cephalon deeper than in other illustrated specimens; $H-R$, a series of primitive and derived species of Irvingella. H-J, Irvingella angustilimbata (Kobayashi, 1938). H, cranidium, I, J, cranidium (J, anterior view, latex cast), DB19.72, 108.12 $\mathrm{m}$ above the base of Huayansi Formation, $\times 7, \times 4.5, \times 4.5 ; \mathrm{K}-\mathrm{N}$, Irvingella convexa (Kobayashi, 1935). $K, L$ and $M, N$, two cranidia (L and $N$ in anterolateral views), DB30.6, $119 \mathrm{~m}$ above the base of Huayansi Formation, $\times 5.7, \times 5.7, \times 4, \times 4$; O-R, Irvingella major Ulrich and Resser in Walcott, 1924. O, P, cranidium (P in anterior view), $R$, pygidium, DB31.1, $119.5 \mathrm{~m}$ above the base of Huayansi Formation, $\times$ 4.2, × 4.2, × 10; Q, cranidium, DB33.6, $122 \mathrm{~m}$ above the base of Huayansi Formation, $\times$ 4.5; S, Tomagnostella orientalis (Lazarenko, 1966), exoskeleton, DB31.1, $119.5 \mathrm{~m}$ above the base of Huayansi Formation, $\times$ 9; T, U, Ivshinagnostus hunanensis Peng, 1992, cephalon (latex cast), pygidium, DB28, $116.4 \mathrm{~m}$ above the base of Huayansi Formation, $\times$ 9, $\times$ 9.5; V, W, Eolotagnostus sp. nov., cephalon, pygidium, DB33.6, $122 \mathrm{~m}$ above the base of Huayansi Formation, $\times 14, \times 8 ; \mathrm{X}$, Y, Proceratopyge (Sinoproceratopyge) distincta Lu and Lin, 1989, cranidium, pygidium, DB33.6, $122 \mathrm{~m}$ above the base of Huayansi Formation, $\times$ 7, × 6; Z, Corynexochus plumula Öpik, 1963, cranidium, DB9.7, 98.1 $m$ above the base of Huayansi Formation, $\times 12$. 


\begin{tabular}{|c|c|c|c|c|c|c|c|c|c|c|}
\hline \multirow{2}{*}{\multicolumn{4}{|c|}{$\begin{array}{c}\text { Zhejiang, South China } \\
\text { (this study) }\end{array}$}} & \multirow{2}{*}{\multicolumn{2}{|c|}{$\begin{array}{l}\text { Hunan, South China } \\
\text { Dong et al., } 2004\end{array}$}} & \multicolumn{3}{|c|}{ North and Northeast China } & \multirow{2}{*}{\multicolumn{2}{|c|}{$\begin{array}{c}\text { Great Basin, USA } \\
\text { Miller, } 1981 \\
\text { Miller et al., } 2006\end{array}$}} \\
\hline & & & & & & & An, 1 & 1982; Wang, 1985 & & \\
\hline$\stackrel{\substack{\infty \\
\oplus}}{\infty}$ & 离 & 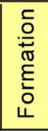 & $\begin{array}{l}\text { Conodont Zone } \\
\text { and Subzone }\end{array}$ & 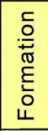 & Conodont Zone & 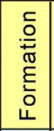 & & $\begin{array}{l}\text { Conodont Zone } \\
\text { and Subzone }\end{array}$ & 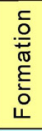 & $\begin{array}{l}\text { Conodont Zone } \\
\text { and Subzone }\end{array}$ \\
\hline \multirow{5}{*}{ 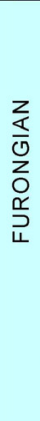 } & \multirow{4}{*}{ 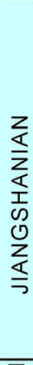 } & \multirow{3}{*}{ 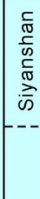 } & & \multirow{3}{*}{ 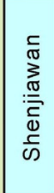 } & \multirow{2}{*}{ Proconodontus } & \multirow{3}{*}{ 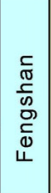 } & \multirow{3}{*}{ 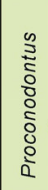 } & \multirow{2}{*}{$\begin{array}{l}\text { Proconodonius } \\
\text { muelleri }\end{array}$} & \multirow{3}{*}{$\begin{array}{l}\text { L } \\
0 \\
0 \\
0 \\
\frac{1}{0} \\
0 \\
\frac{0}{2}\end{array}$} & $\begin{array}{l}\text { Proconodontus } \\
\text { muelleri }\end{array}$ \\
\hline & & & & & & & & & & $\begin{array}{l}\text { Proconodontus } \\
\text { posterocostatus }\end{array}$ \\
\hline & & & & & $\begin{array}{l}\text { Proconodontus } \\
\text { tenuiserratus }\end{array}$ & & & $\begin{array}{l}\text { Proconodonius } \\
\text { tenuiserratus }\end{array}$ & & $\begin{array}{l}\text { Proconodontus } \\
\text { tenuiserratus }\end{array}$ \\
\hline & & \multirow{2}{*}{ 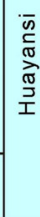 } & \multirow[t]{2}{*}{$\begin{array}{l}\text { W. cf. calix- } \\
\text { Prooneotodus } \\
\text { rotundatus }\end{array}$} & \multirow{2}{*}{ 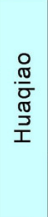 } & $\begin{array}{l}\text { Westergaardodina } \\
\text { cf. callix - }\end{array}$ & \multirow{2}{*}{$\begin{array}{l}\frac{c}{\pi} \\
\frac{5}{\omega} \\
\frac{\pi}{\pi} \\
\frac{\pi}{0}\end{array}$} & \multicolumn{2}{|c|}{$\begin{array}{l}\text { Westergaardodina } \\
\text { aff. fossa - P. rotundatus }\end{array}$} & \multirow{2}{*}{\multicolumn{2}{|c|}{$\begin{array}{l}\text { No zonation } \\
\text { established }\end{array}$}} \\
\hline & 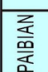 & & & & $\begin{array}{c}\text { Westergaardodina lui - } \\
\text { W. ani }\end{array}$ & & \multicolumn{2}{|r|}{ Muellerodus? erectus } & & \\
\hline
\end{tabular}

Figure 10. Tentative biostratigraphic correlation of the Westergaardodina $c f$. calix Prooneotodus rotundatus conodont Zone in the Duibian B section with other areas.

Proceratopyge (Sinoproceratopyge) kiangshanensis Zone (Peng, 1992). Downsection the Huaqiao Formation contains a few carbonate debris beds in the Glyptagnostus reticulatus Zone suggesting that the Huaqiao Formation near Shenjiawan represents a somewhat less deep slope environment than does the Huayansi Formation of the Duibian sections.

\section{Extraregional Reference Sections}

Two extraregional sections were considered by the ISCS as potential stratotype sections for the GSSP of the Jiangshanian Stage. Both are well exposed, well documented, have an inferred complete succession of strata through the base of the $A$.

is associated with the onset of a small-scale transgressive event (Zuo, 2006, fig. 4). The regression with which the FAD of A. orientalis is associated is interpreted to be of eustatic scale.

\section{Other Regional Reference Section}

Apart from the Duibian A section, western Zhejiang, there is another well-exposed section in South China, which yields the primitive morphotype of $A$. orientalis. The section is located near Shenjiawan in the Cili-Taoyuan area, Hunan Province, China. It exposes limestone deposits of the upper part of the Huaqiao Formation, which were formerly referred to the lower part of the Bitiao Formation by Peng (1992). The first observed occurrence of $A$. orientalis in the section is about $42 \mathrm{~m}$ above the base of the Corynexochus plumula-

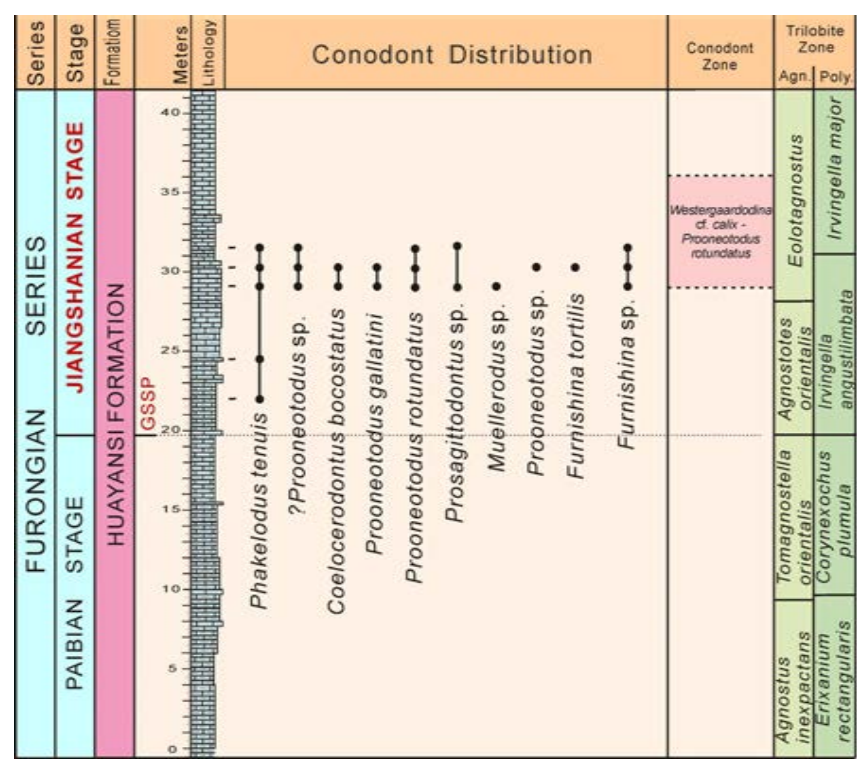

Figure 11. Observed stratigraphic distribution of conodonts in the Huayansi Formation near the base of the Agnostotes orientalis Zone, Duibian B section, Jiangshan, Zhejiang, China. Agn.= agnostoid trilobite biostratigraphic zonation; Poly. $=$ polymerid trilobite biostratigraphic zonation. orientalis Zone, and meet all of the major requirements for a GSSP. In both cases, though, accessibility is less easy than in the case of the Duibian section. Nevertheless, the Cambrian Subcommission considers both extraregional sections to be important for correlation purposes both regionally and globally.

The first extraregional section occurs along the Kyrshabakty River, about 28 km northeast of Zhanatas, Malyi Karatau Range, Kazakhstan (Ergaliev, 1980; Ergaliev and Ergaliev, 2000, 2008). The base of the section is located at $43^{\circ} 32^{\prime} 02^{\prime \prime} \mathrm{N}, 69^{\circ} 51^{\prime} 28^{\prime \prime} \mathrm{E}$ and an elevation of $527 \mathrm{~m}$. It is located in a protected area, the Aksai State Natural Reserve, but accessible for study. The Malyi Karatau Range represents a northwestern extension of the Tien Shan Mountains. The Kyrshabakty section was long considered a major reference section for stratigraphic subdivisions of the historic Middle and Upper Cambrian of the former USSR, and later for Kazakhstan (Ergaliev and Ergaliev, 2000; Ergaliev et al., 2009).

In the Kyrshabakty section, Cambrian strata ranging from the upper part of the Paibian Stage through the Jiangshanian Stage are assigned to the Bestogai Formation, a succession dominated by medium gray to dark gray, thin to medium bedded limestones (lime mudstones); some limestone turbidites with packstone texture are present. The first appearance of $A$. orientalis is $61.2 \mathrm{~m}$ above the base of Unit 8 in the Bestogai Formation (and $259 \mathrm{~m}$ above the base of the measured section). A. orientalis is rare at this locality. The first appearance of $A$. orientalis in this section is $2.0 \mathrm{~m}$ above the first appearance of the polymerid trilobite Irvingella angustilimbata (commonly cited at this locality under the name of a junior synonym, I. tropica).

Cambrian Series 3 and Furongian strata exposed in the Kyrshabakty section were deposited on a prograding margin of an isolated carbonate platform called the Aisha-Bibi Seamount (Cook et al., 1991). Detailed bed-by-bed correlation, coupled with detailed biostratigraphy, suggest that the Zhumabai and overlying Bestogai formations record a complete, essentially continuous stratigraphic succession. The FAD of A. orientalis is in a bed within the Bestogai Formation, immediately overlying a carbonate turbidite that extends over part of the outcrop. However, the turbidite pinches out approximately $50 \mathrm{~m}$ away from the line of the measured section, and the $A$. orientalis-bearing bed can be traced laterally from the line of 


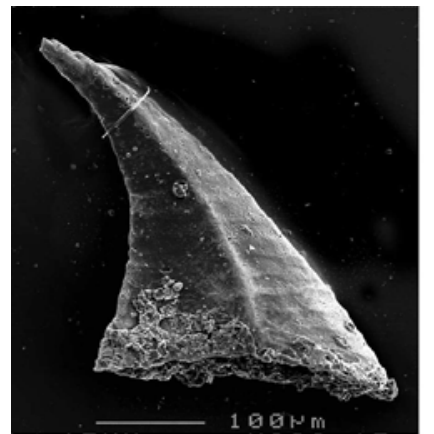

A

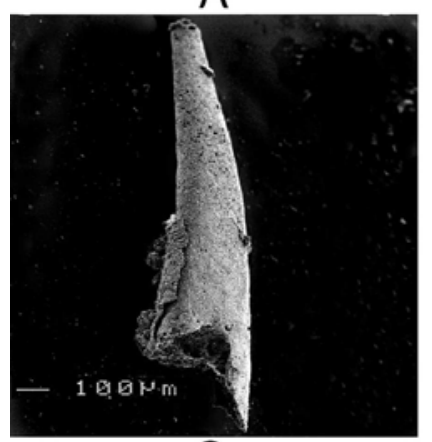

C

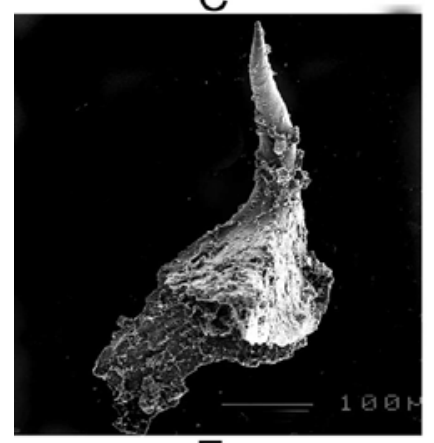

E

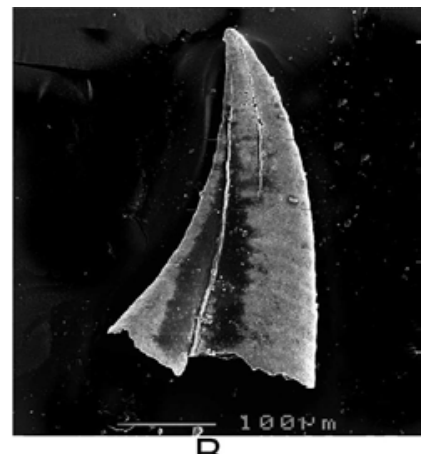

B

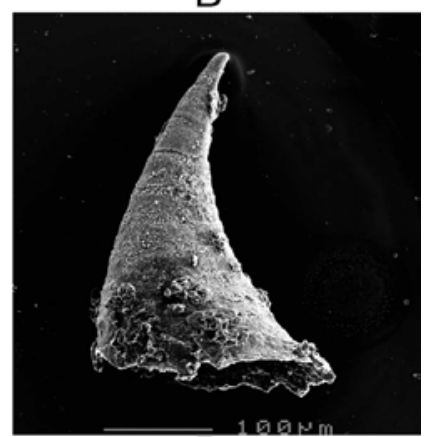
$\mathrm{D}$

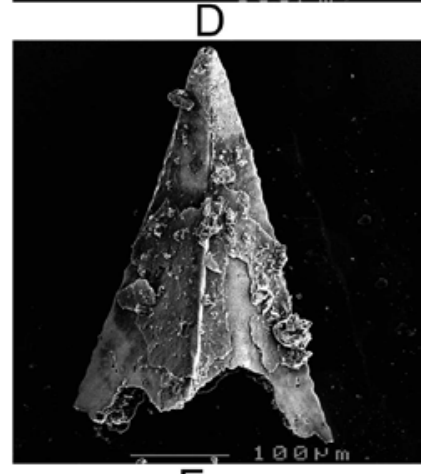

$\mathrm{F}$
Figure 12. Conodonts used for constraining the base of the Jiangshanian Stage. A, Coelocerodontus bicostatus van Wamel, 1974; sample DBC30.3, $118.7 \mathrm{~m}$ above the base of Huayansi Formation, lateral view, $\times 120$. B, Coelocerodontus bicostatus van Wamel, 1974; sample DBC30.3, $118.7 \mathrm{~m}$ above the base of Huayansi Formation, lateral view, $\times 110$. $C$, ?Prooneotodus sp.; sample DBC29.12, $117.52 \mathrm{~m}$ above the base of Huayansi Formation, posterolateral view, × 36. D, Prooneotodus gallatini (Müller, 1959); sample DBC30.3, $118.7 \mathrm{~m}$ above the base of Huayansi Formation, lateral view, $\times 120 . E$, Furnishina tortilis (Müller, 1959); sample DBC30.3, $118.7 \mathrm{~m}$ above the base of Huayansi Formation, posterolateral view, $\times$ 90. F, Prosagittodontus sp.; sample DBC31.5, $119.9 \mathrm{~m}$ above the base of Huayansi Formation, posterior view, $\times 110$.

the measured section. The order of trilobite occurrences is consistent with an unbroken stratigraphic succession.

The second extraregional section occurs along the Khos-Nelege River, Siberia, near where it joins the Neleger River. The Neleger River is a tributary to the much larger Lena River. The section is located about $25 \mathrm{~km}$ northeast of the village of Chekurovka and 60 $\mathrm{km}$ southwest of the town of Tiksi, in the Kharaulakh Mountains (southern part of the Tuora-Sis Ridge), North Verkhoyanie, western part of the Republic of Sakha (Yakutia), Russia (Lazarenko et al., 2008a, b). The base of the Jiangshanian Stage is located $500 \mathrm{~m}$ upstream from the junction of the Khos-Nelege River with the Neleger River, at a position of $71^{\circ} 14^{\prime} 36^{\prime \prime} \mathrm{N}, 127^{\circ} 31^{\prime} 35^{\prime \prime} \mathrm{E}$. The section is exposed in the western limb of the Chekurovian anticline of the Verkhoyansk folded area, northeastern part of the Siberian Platform. This area, at the mouth of the Khos-Nelege River, is located in the Lena Delta Research Reservation, part of the Ust'-Lenskij State Natural Reserve. The land is public, under permanent protection of the government of the Republic of Sakha (Yakutia), and accessible for research. Access to the site is limited by weather conditions in the Arctic, with July and August being the optimal times for field research.

In the Khos-Nelege River section, Cambrian strata ranging from the Drumian Stage through the Jiangshanian Stage are assigned to the Ogon'or Formation, a succession dominated by rhythmic, thinto thick-bedded, dark gray carbonates (wackestones to packstones), carbonate shales and silty limestones, intercalated with bioturbated limestones and shales. The FAD of A. orientalis is $213.3 \mathrm{~m}$ above the base of the Ogon'or Formation (and $3.3 \mathrm{~m}$ below the top of bed 32). The first appearance of A. orientalis in this section occurs close to the first appearances of two species of the polymerid trilobite Irvingella, I. megalops and I. major. I. megalops first appears 210.5 $\mathrm{m}$ above the base of the Ogon'or Formation, and I. major first appears $219.6 \mathrm{~m}$ above the base of the formation. Thus, the first appearance of $A$. orientalis is $2.8 \mathrm{~m}$ above the first appearance of $I$. megalops, and $6.3 \mathrm{~m}$ below the first appearance of I. major.

Cambrian strata of eastern Siberia were deposited within the vast Yudoma-Olenek Basin, which opened to the east (Lazarenko et al., 1990; Sukhov, 1997). The Khos-Nelege River section exposes a northern sublongitudinal slope of this basin. One shelf margin of the basin, a carbonate platform edge, is exposed 20 to $30 \mathrm{~km}$ to the north in the Bulkur anticline. Detailed bed-by-bed correlation, coupled with detailed biostratigraphy, suggests that the Ogon'or Formation records a complete, essentially continuous stratigraphic succession. The order of trilobite occurrences is consistent with an unbroken stratigraphic succession.

\section{Best Estimate of Age for the Base of the Jiangshanian Stage}

Shergold (1995) estimated an age of 500 Ma for the traditional Middle-Upper Cambrian boundary, and that position is close to the base of the Linguagnostus reconditus Zone of South China (Peng and Robison, 2000; Ahlberg, 2003; Ahlberg et al., 2004). This boundary is two agnostoid zones lower than the conterminant base of the Furongian Series and Paibian Stage. Peng and Robison (2000) suggested that the average duration for a single agnostoid zone is about 1 m.y. If so, the base of the Furongian Series is likely to have an age of $\sim 498 \mathrm{Ma}$.

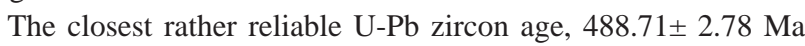
(Davidek et al., 1998; Peng et al., 2009a), comes from within the Furongian Series. This radioisotopic age derives from a crystal-rich volcaniclastic sandstone in the Peltura scarabaeoides Zone (Dolgellau Formation) at Ogof-ddû, near Criccieth, North Wales. This age constrains the top of the Lotagnostus americanus Zone of South China and elsewhere to a great extent because the last occurrence of $L$. americanus [=Lotagnostus trisectus Salter] in Sweden is within the lower P. scarabaeoides Zone as used historically (Westergård, 1922; Ahlberg and Ahlgren, 1996). In Sweden, this position is now referred (Terfelt et al., 2008, 2011) to the top of the Lotagnostus americanus 
Zone (agnostoid zonation) and the Ctenopyge linnarssoni Zone (polymerid trilobite zonation). The interval of the $L$. reconditus Zone through the Lotagnostus americanus Zone should have had a duration of 8 to11 million years because about 8 biostratigraphic zones are recognized in China (Peng, 1990, 1992; Shergold and Copper, 2004) and 11 zones are recognized for the comparable interval in Australia (Shergold and Cooper, 2004); the average duration of each zone is assumed to be 1 million years or less. This yields a best age estimate of $494 \mathrm{Ma}$, or slightly older, for the base of the A. orientalis Zone (i.e., the base of the Jiangshanian Stage), which is three zones above the base of the Glyptagnostus reticulatus Zone. Because we have only one reliable isotopic age date within the Furongian Series, estimation of age of the base of the Jiangshanian Stage is made with less confidence than the estimate for the base of the Guzhangian Stage. The Guzhangian age was based on multiple numerical age dating sources (summarized in Peng et al., 2009b).

\section{Acknowledgements}

We would like to thank all the people, including members of the ISCS, involved in the process of defining the base of the Jiangshanian for stimulating discussion and scientific support. Li Quan and Zhou Chuanming are thanked for assisting in field. We thank Per Ahlberg (Lund University), Svend Stouge (University of Copenhagen) and an anonymous reviewer for their valuable comments and constructive suggestions, which helped to improve the manuscript. This work was supported in part by grants from the State Key Laboratory on Palaeobiology and Stratigraphy, (20091103; 20121101), the Ministry of Science and Technology of China (2006FY120300), the National Natural Science Foundation of China (41290260, 41221001), and the National Commission on Stratigraphy of China to Peng.

\section{References}

Ahlberg, P., 2003, Trilobites and international tie points in the Upper Cambrian of Scandinavia: Geologica Acta, v. 1, pp. 127-134.

Ahlberg, P. and Ahlgren, J., 1996, Agnostids from the Upper Cambrian of Västergötland, Sweden: GFF, v. 118, pp.129-140.

Ahlberg, P., Axheimer, N., Eriksson, M.E., and Terfelt, F., 2004, Agnostoids and international tie points in the middle and upper Cambrian of Scandinavia, in Mansfeld, J. (ed.), The $26^{\text {th }}$ Nordic Geological Winter Meeting, Abstract Volume: GFF, v. 126 (1), p. 108.

An, T.X., 1987, The Lower Paleozoic Conodonts of South China: Beijing, The Publishing House of Peking University, 238 pp.

Babcock, L.E., Peng, S.C., Geyer, G., and Shergold, J.H., 2005, Changing perspectives on Cambrian chronostratigraphy and progress toward subdivision of the Cambrian System: Geosciences Journal, v. 9, pp. 101106.

Chatterton, B.D.E., and Ludvigsen, L. 1998, Upper Steptoean (Upper Cambrian) trilobites from the McKay Group of southeastern British Columbia, Canada: Journal of Paleontology (Supplement), v. 72(2) , 43 pp.

Choi, D.K., 2004, Stop 12, Machari Formation at the Gonggiri section, in Choi, D.K., Chough, S.K., Fithes, W. R., Kwon, Y.K., Lee, S.-B., Kang, I., Woo, J., Shinn, Y.J. and Sohn, J. W. (eds), Field Trip Guide for IX International Conference of the Cambrian Stage Subdivision Working Group, Cambrian in the Land of Morning Calm: Paleontological Society of Korea, Special Publication, v. 8, pp. 51-56.

Choi, D.K., Lee, J.G., and Sheen, B.C., 2004, Upper Cambrian agnostoid trilobites from the Machari Formation, Yongwol, Korea: Geobios, v. 27, pp. 159-189.
Choi, D.K., Chough, S.K., Kwon, Y.K., and Lee, S.B., 2005, CambrianOrdovician Joeseon Supergroup of the Taebaksan Basin, Korea, in Peng, S.C., Babcock, L.E., and Zhu, M.Y. (eds), Cambrian System of China and Korea: Hefei, China University of Science and Technology of China Press, pp. 265-300.

Cook, H.E., Taylor, M.E., Zhemchuzhnikov, V.G., Apollonov, M.K., and Ergaliev, G. Kh. 1991, Comparison of two early Paleozoic carbonate submarine fans, western United States and southern Kazakhstan, Soviet Union: Paleozoic Paleogeography of the Western United States-II. Pacific Section SEPM, v. 67, pp. 847-872.

Davidek, K.L., Landing, E., Bowring, S.A., Westrop, S.R., Rushton, A.W.A., Fortey, R.A., and Adrain, J., 1998, New uppermost Cambrian U-Pb date from Avalonian Wales and age of the Cambrian-Ordovician boundary: Geological Magazine, v. 133, pp. 303-309.

Dong, X.P., Repetski, J.E., and Bergström, S.M., 2004, Conodont biostratigraphy of the Middle Cambrian through Lowermost Ordovician in Hunan, South China: Acta Geologica Sinica, v. 78, pp. 1185-1206.

Duan, Y., 2003, New polymerid trilobite and the first record of Erixanium from Upper Cambrian in western Hunan, China: Acta Paleontologica Sinica, v. 43, pp. 63-71.

Ergaliev, G.Kh., 1980, Middle and Upper Cambrian trilobites of the Malyi Karatau Range: Alma-Ata, Publishing House of Kazakhstan SSR, $211 \mathrm{pp}$.

Ergaliev, G.Kh., and Ergaliev, F.G., 2000, Biostratigraphy of Cambrian of Karatau Range - basis of unified scale of Cambrian deposits of Central Asia: Geodynamic and Mineralogy of Kazakhstan, v. 2000, pp. 119134.

Ergaliev, G.Kh., and Ergaliev, F.G., 2008, Middle and upper Cambrian Agnostida of the Aksai National Geological Reserve South Kazakhstan (Kyrshabakty River, Malyi Karatau Range): Almaty, Gylym, 376 pp.

Ergaliev, G.Kh., Zhemchuzhnikov, V.G., Ergaliev, F.G., Bassett, M.G., Popov, L., and Holmer, L., 2009, The Kyrshabakty section in the Malyi Karatau Range, South Kazakhstan, the proposed potential global standard stratotype-section and point for the Suzak Stage of the Furongian Series (upper Cambrian), in Ergaliev, G.Kh., Zhemchuzhnikov, V.G., Popov, L. et al. (eds), Field Excursion Guide, $14^{\text {th }}$ International Field Conference of the Cambrian Stage Subdivision Working Group, Malyi Karatau Range, southern Kazakhstan: Almaty-Karatau, K.I. Satpaev Institute of Geological Sciences, pp. 38-71.

Geyer, G., and Shergold, J., 2000, The quest for internationally recognized divisions of Cambrian time: Episodes, v.23, pp. 188-195.

Hong, P., and Choi, D.K., 2003, The Late Cambrian trilobite Irvingella from the Machari Formation, Korea: evolution and correlation: Special Papers in Palaeontology, v. 70, pp. 175-196.

Jiangxi Bureau of Geology and Mineral Resources, 1984, Regional Geology of Jiangxi Province. People's Republic of China, Ministry of Geology and Mineral Resources, Geological Memoirs, series 1, number 2: Beijing, Geological Publishing House, 921 pp.

Kobayashi, T., 1935, The Cambro-Ordovician formations and faunas of South Chôsen, Palaeontology. Part 3, Cambrian faunas of South Chôsen with a special study on the Cambrian trilobite genera and families: Journal of the Faculty of Science, Imperial University of Tokyo, Section II, v. 4(2), pp. 49-344.

Kobayashi, T., 1938, Upper Cambrian fossils from British Columbia with a discussion on the isolated occurrence of the so-called 'Olenus' beds of Mt. Jubilee: Japanese Journal of Geology and Geography, v. 15, pp. 147-192.

Lazarenko, N.P., 1966, Biostratigraphy and some new trilobites of the Upper Cambrian Olenek Rise and Kharaulakh Mountains: Research Academic Bulletin of Palaeontology and Biostratigraphy [ Uchenie Zapisky Paleontologiya i Biostratigrafiya] (NIIGA), v. 11, pp. 33-78.

Lazarenko, N.P., Jegorova, L.I., Pegel, T.V., Sukhov, S.S., Federov, A.B., Abaimova, G.P., Vaganova, N.V., and Zakharov A.V., 1990, The Cambrian of Chekurov anticline, Kharaulakh Mountains (northeastern outlying area of Siberian Platform), in Repina, L.N., and Zhuravlev, A. J. (eds), Third International Symposium on the Cambrian System, Novosibirsk, USSR, Abstracts: Novosibirsk, p. 129. 
Lazarenko, N.P., Gogin, I.Y., Pegel, T.V., Sukhov, S.S., Abaimova, G. P., Egorova., L.I., Fedorov, E.G., Raevskaya, G.T., and Ushatinskaya, G.T., 2008a, Excursion 1b. Cambrian stratigraphy of the northeastern Siberian Platform and potential stratotype of lower boundaries of the proposed Upper Cambrian Chekurovkian and Nelegerian stages in the Ogon'or Formation section and Khos-Nelege River; the boundaries and defined by the FAD of Agnostotes orientalis and Lotagnostus americanus, in Rozanov, A.Yu and Varlamov, A.I (eds), The Cambrian System of the Siberian Platform, Part 2, North-East of the Siberian Platform: MoscowNovosibirsk,PIN RAS, pp. 61-106.

Lazarenko, N.P., Pegel, T.V., Sukhov, S.S., Abaimova, and Gogin, I.Y., 2008b, Type section of Upper Cambrian, Siberian Platform - candidate for stage stratotype of international stratigraphical scale (Khos-Nelege River, western Yakutia, Russia), in Budnikov, I.V. (ed.), Cambrian sections of Siberian Platform - candidates of stage subdivision of international stratigraphical scale (stratigraphy and palaeontology), Material for $13^{\text {th }}$ International Field Conference of the Working Group on Cambrian Stage Subdivision: Novosibirsk, Press of Siberian Branch RAN, pp. 3-58.

Lu, Y.H., 1964, Cambrian trilobites, in Wang, Y. (ed.), A Handbook of Index Fossils of South China: Beijing, Science Press, 26-39 pp.

Lu, Y.H., and Lin, H.L., 1981, Zonation of Cambrian faunas in the western Zhejiang and their correlation with those in North China, Australia and Sweden, in Short Papers for the Second International Symposium on the Cambrian System, 1981: United States Department of the Interior Geological Survey, Open-File Report, 81£-743, pp. 118-120.

Lu, Y.H., and Lin, H.L., 1983, Zonation and correlation of Cambrian faunas in W Zhejiang: Acta Geologica Sinica, v. 57(4) , pp. 317-328.

Lu, Y.H., and Lin, H.L., 1989, The Cambrian trilobites of western Zhejiang: Palaeontologica Sinica, New Series B, no. 25, (whole no.178), Beijing, Science Press, 287 pp.

Lu, Y.H., Zhang, W.T., Zhu, Z. L., Qian, Y.Y., and Xiang L.W., 1965, Fossils of Each Group of China, Chinese Trilobites: Beijing, Science Press, 766 pp. (2 vols.)

Lu, Y.H., Zhu Z.L., Qian, Y.Y., Lin, H.L., Zhou, Z.Y., and Yuan, K.X, 1974, The bio-environmental control hypothesis and its application to the Cambrian biostratigraphy and palaeozoo-geography: Nanjing Institute of Geology and Palaeontology, Academia Sinica, Memoir, v. 5, pp. 27110.

Lu, Y.H, Lin, H.L, Han, N.R, Li, L.Z., and Ju, T.Y., 1983, CambrianOrdovician Boundary of Jiangshan-Changshan area, in Papers for the Symposium on the Cambrian-Ordovician and Ordovician-Silurian boundaries, China: Nanjing, Nanjing Institute of Geology and Palaeontology, Academia Sinica, pp. 1-5.

Lu, Y.H, Lin, H.L, Han, N.R, Li, L.Z., and Ju, T.Y., 1984, On the CambrianOrdovician boundary of the Jianshan-Changshan area, W Zhejiang, in Stratigraphy and Palaeontology of Systemic Boundaries in China. Cambrian-Ordovician Boundary (1) : Hefei, Anhui Science and Technology Publishing House, pp. 9-44.

Mei M.X., Zang C., Zang, H., Meng X.Q., and Chen Y.H., 2007, Sequencestratigraphic frameworks for the Cambrian of the Upper-Yangtze Region: ponder on the forming background of the Cambrian biological diversity events: Journal of Stratigraphy, v. 31, pp. 68-78.

Miller, J.F., 1981, Paleozoogeography and biostratigraphy of Upper Cambrian and Tremadocian conodonts: United States Geological Survey Open-File Report, 81-743, pp. 134-137.

Miller, J.F., Ethington, R.L., Evans, K.R., Holmer, L.E., Loch, J.D., Popov, L.E., Repetski, J.F., Rippendan, R.L., and Taylor, J.F., 2006, Proposed stratotype for the base of the highest Cambrian stage at the first appearance datum of Cordylodus andresi, Lawson Cove section, Utah, USA: Palaeowold, v. 15, pp. 384-405.

Mitchell, C.E., Chen, X., BergströM, S.M., Zhang, Y.D., Wang, Z.H., Webby, B.D., and Finney, S.C. , 1997, Definition of a global boundary stratotype for the Darriwilian Stage of the Ordovician System: Episodes, v. 20, pp. 158-166.

Müller, K.J., 1959, Kambrische Conodonten: Zeitschrift der Deutschen Geologische Gesellschaft, v. 111, pp. 434-485.
Öpik, A.A., 1963, Early Upper Cambrian fossils from Queensland: Australia Bureau of Mineral Resources Geology \& Geophysics Bulletin, v. 64, 133 pp.

Öpik, A.A., 1967, The Mindyallan fauna of northwestern Queensland: Australia Bureau of Mineral Resources, Geology and Geophysics Bulletin v. 74 (2 Volumes), $404+167$ pp.

Palmer, A.R., 1965, Trilobites of the Late Cambrian Pterocephaliid Biomere in the Great Basin, United States: United States Geological Survey Professional Paper 493, 105 pp.

Pegel, T.V., 2000, Evolution of trilobite biofacies in Cambrian basins of the Siberian Platform: Journal of Paleontology, v. 74, pp. 1000-1019.

Peng, S.C., 1990, Upper Cambrian in the Cili-Taoyuan Area, Hunan and its trilobite succession: Journal of Stratigraphy, v. 14, pp. 261-276.

Peng, S.C., 1992, Upper Cambrian biostratigraphy and trilobite faunas of the Cili-Taoyuan area, north-western Hunan, China: Association of Australasian Palaeontologists, Memoir 13, 119 pp.

Peng, S.C., 2000, Chapter 2, Cambrian of Slope Facies (of China), in Nanjing Institute of Geology and Palaeontology, Chinese Academy of Sciences (ed.), Stratigraphical Studies in China (1979-1999): Beijing, Geological Publishing House, pp. 23-38.

Peng, S.C., 2003, Chronostratigraphic subdivision of the Cambrian of China: Geologica Acta, v. 1, pp. 135-144.

Peng, S.C., and Babcock, L.E., 2001, Cambrian of the Hunan-Guizhou region, South China, in Peng, S.C., Babcock, L.E., and Zhu M.Y. (eds), Cambrian System of South China: Hefei, University of Science and Technology of China Press, pp. 3-51.

Peng S.C., and Babcock, L. E., 2005a, Newly proposed global chronostratigraphic subdivision on Cambrian System: Journal of Stratigraphy, v. 29, pp. 92, 93, 96.

Peng S.C., and Babcock, L.E, 2005b, Two Cambrian agnostoid trilobites, Agnostotes orientalis (Kobayashi, 1935) and Lotagnostus americanus (Billings, 1860): key species for defining global stages of the Cambrian System: Geoscience Journal, v. 9, pp. 107-115.

Peng, S.C., Babcock, L.E., and Cooper, R.A., 2012, The Cambrian System, in Gradstein, F.M., Ogg, J.G., Schmitz, M.D., and Ogg, G.M. (eds), The Geologic Time Scale 2012: Boston, Elsevier, pp. 451-502.

Peng, S.C., Babcock, L.E., Lin, H.L., Zuo, J.X., Zhu, X.J., Zhou, C.M., Yang, X.F., Qi, Y.P., and Li Q., 2006, Potential global standard stratotype-sections (GSSP) at Luoyixi, NW Hunan and Duibian, W Zhejiang, South China for undefined Cambrian Stage 7 and Cambrian Stage 9, in J. B. Jago (ed.). South Australia, XI International Conference of the Cambrian Stage Subdivision Working Group Sydney, Geological Society of Australia, p. 30

Peng, S.C., Babcock, L.E., Robison, R.A., Lin, H.L., Rees, and M.N. Saltzman, M.R. 2004, Global Standard Stratotype-section and Point (GSSP) of the Furongian Series and Paibian Stage (Cambrian). Lethaia, v. 37, pp. 365379.

Peng, S.C., Babcock, L., Zuo, J.X., Lin, H.L., Zhu, X.J., Yang, X.F., Qi, Y.P., Bagnoli, G., and Wang, L.W., 2009a, Potential GSSP for the base of Cambrian Stage 9, coinciding with the first appearance of Agnostotes orientalis, Zhejiang, China: Science in China D, Earth Sciences, v. 52 (4), pp. 434-451.

Peng, S.C., Babcock, L.E., Zuo, J.X., Lin, H.L., Zhu, X.J., Yang, X.F., Robison, R.A., Chi, Y.P., Bagnoli, G., and Chen, Y., 2009b, The Global boundary Stratotype Section and Point (GSSP) of the Guzhangian Stage (Cambrian) in the Wuling Mountains, northwestern Hunan, China: Episodes, v. 32, pp. $41-55$

Peng, S.C., and Robison, R.A. 2000, Agnostoid biostratigraphy across the middle-upper Cambrian boundary in Hunan, China: Journal of Paleontology (supplement), v. 74(4), pp. 1-104.

Peng S.C., Zuo J.X., Babcock, L. E., Lin H.L., Zhou C.M., Yang X.F., and Li Q., 2005, Cambrian sections at Dadoushan near Duibian, Jiangshan, western Zhejiang Province and candidate stratotype for the base an unnamed global stage defined by the FAD of Agnostotes orientalis, in Peng, S.C., Babcock, L.E., and Zhu, M.Y. (eds), Cambrian System of China and Korea: Hefei, University of Science and Technology of China Press, pp. 210-227. 
Pratt, B.R., 1992, Trilobites of the Marjuman and Steptoean stages (Upper Cambrian), Rabbitkettle Formation, southern Mackenzie Mountains, northwest Canada: Palaeontographica Canadiana, v. 9, 179 pp.

$\mathrm{Pu}$, X.C., and Ye, H.Z., 1991, Cambrian sedimentary facies and palaeogeography framework in southern China: Collected Papers of Lithofacies and Paleogeography, v. 6, pp. 1-16.

Remane, J., Basset, M.G., Cowie, J.W., Gohrbandt, K.H., Lane, H.R., Michelsen, and O., Wang, N.W., 1996, Revised guidelines for the establishment of global chronostratigraphic standards by the International Commission on Stratigraphy (ICS): Episodes, v. 19, pp. 77-81.

Robison, R.A., 1984, Cambrian Agnostida of North America and Greenland, Part I, Ptychagnostidae: University of Kansas Paleontological Contributions Paper, v. 109, pp. 1-59.

Rozova, A.B.,1963, Biostratigraphic scheme for the Upper and upper Middle Cambrian and new Upper Cambrian trilobites from Kuliumbe River: Geology and Geophysics, v. 1963 (9), pp. 3-19.

Rushton, A.W.A., 1967, The Upper Cambrian trilobite Irvingella nuneatonensis (Sharman): Palaeontology, v. 10, pp. 339-384.

Rushton, A.W.A., 1983, Trilobites from the Upper Cambrian Olenus Zone in central England: Palaeontology, v. 30, pp. 107-139.

Shergold, J.H., 1993, The Iverian Stage (Late Cambrian) and its subdivision in the Burke River structural belt, western Queensland: BMR Journal of Australian Geology and Geophysics, v. 13(4), pp. 345-358.

Shergold, J.H., 1995, Timescale 1. Cambrian: Australian Geological Survey Organization, Record 1995/30.

Shergold, J.H., and Geyer, G. 2001, The International Subcommission on Cambrian Stratigraphy: progress report 2001: Acta Palaeontologica Sinica, v. 40 (Supplement), pp. 1-3.

Shergold, J., and Cooper, R.A., 2004, Cambrian Period, in Gradstein, F., Ogg, J., and Smith, A. (eds), A Geological Time Scale 2004. Cambridge University Press, U.K., pp. 147-164.

Sukhov, S.S., 1997, Cambrian depositional history of the Siberian craton: evolution of the carbonate platforms and basins: Sedimentary Facies and Palaeogeography, v. 17 (5), pp. 27-39.

Terfelt, F., Eriksson, M.E., Ahlberg, P., and Babcock, L.E., 2008, Furongian

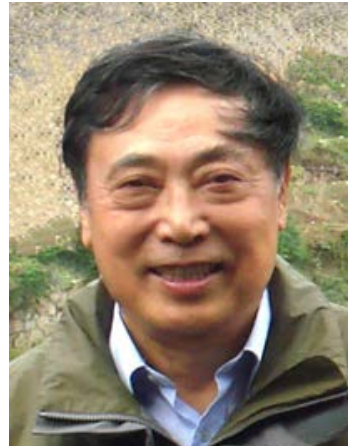

Shanchi Peng is a Research Professor at the Nanjing Institute of Geology and Palaeontology, Chinese Academy of Sciences. He has been working on Cambrian stratigraphy and Cambrian and Ordovician trilobite paleontology since 1978. Recently he focuses his research on global and Chinese chronostratigraphy of the Cambrian System. He is Vice-Chairman of the International Commission on Stratigraphy from 2008.

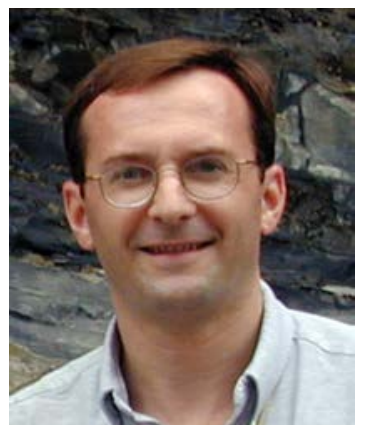

Loren E. Babcock is a Professor in the School of Earth Sciences at the Ohio State University, Columbus, Ohio, USA. His research interests are centered around trilobite paleobiology, taphonomy, and stratigraphy. In recent years, Babcock has focused attention on development of a global chronostratigraphic subdivision of the Cambrian System. He is currently Chairman of the International Subcommission on Cambrian Stratigraphy from 2012.
Series (Cambrian) biostratigraphy of Scandinavia - a revision: Norwegian Journal of Geology, v. 88, pp. 73-87.

Terfelt, F., Ahlberg, P., and Eriksson, M.E., 2011, Complete record of Furongian polymerid trilobites and agnostoids of Scandinavia - a biostratigraphical scheme: Lethaia, v. 44, pp. 8-14.

Varlamov, A.N. and Rozova, A.V., 2009, New regional stages of Upper Cambrian (Evenickyi) of Siberia, in New data on Palaeozoic stratigraphy and palaeontology of Sibera: Novosibirsk, SNIIGGiMS, pp. 3-61.

Varlamov, A.N., Pak, K.L., and Rozova, A.V., 2005, Stratigraphy and trilobites of Upper Cambrian Chopko River section of Norilick Region, NW Siberian Platform: Novosibirsk (SNIIGGiMS), Nauka Press, 82 pp.

Walcott, C.D., 1924, Cambrian and lower Ozarkian trilobites: Smithsonian Miscellaneous Collections, v. 75, pp. 53-60.

Wamel, W.A. van, 1974, Conodont biostratigraphy of the Upper Cambrian and Lower Ordovician of northwestern Öland, southeastern Sweden: Utrecht micropaleontological bulletins, v. 10, pp. 1-101.

Wang, Z.H., 1985, Late Cambrian and Early Ordovician conodonts from North and Northeast China with comments on the Cambrian-Ordovician Boundary, in Nanjing Institute of Geology and Palaeontology Academia Sinica (ed.), Stratigraphy and Paleontology of Systemic Boundaries in China, Cambrian-Ordovician Boundary, (2): Hefei, University of Science and Technology of China Press, pp. 195-238.

Westergård, A.H., 1922, Sveriges olenidskriffer: Sveriges Geologiska Undersökning Series, Ca, v. 18, 205 pp.

Zhang, W.T., 2000, Occurrence of the Pseudoglyptagnostus (Cambrian Trilobita) in South Korea and the significance of the slope biofacies of Korea: Acta Palaeontologica Sinica, v. 39, pp. 92-99.

Zhejiang Bureau of Geology and Mineral Resources, 1989, Regional Geology of Zhejiang Province, People's Republic of China, Ministry of Geology and Mineral Resources, Geological Memoirs, series 1, number 11: Beijing, Geological Publishing House, 688 pp.

Zuo, J.X., 2006, Characteristics of Carbon and Isotopic Composition of Cambrian Carbonates, South China: Nanjing, Postdoctoral Report of the Nanjing Institute of Geology and Palaeontology, Chinese Academy of Sciences, $171 \mathrm{pp}$.

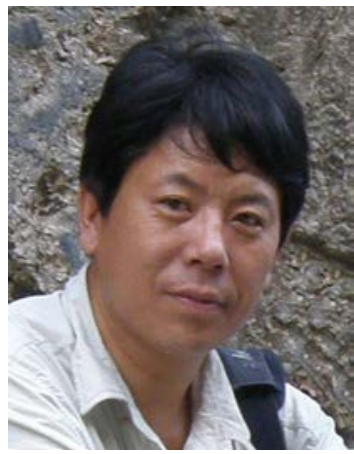

Jingxun Zuo is a Senior Researcher at the Henan Institute of Geological Survey, Zhengzhou, Henan Province, China. His research interests are in sedimentology and chemostratigraphy, with a focus on Cambrian and Triassic isotopic stratigraphy, especially on the studies of carbon and oxygen isotope evolutions for the intervals of potential GSSPs in the upper half of Cambrian and the lower Triassic in South China.

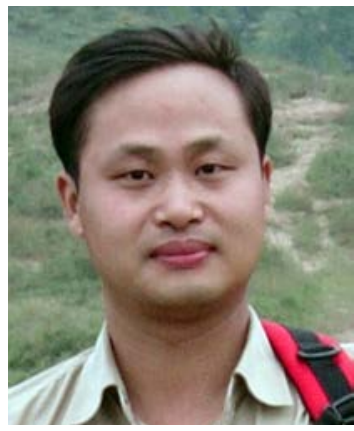

Xuejian Zhu is an Associate Research Professor at the Nanjing Institute of Geology and Palaeontology, Chinese Academy of Sciences (CAS). His research interests are mainly focused on trilobite paleobiology, especially on ontogeny and phylogeny of later Furongian trilobites, and Cambrian stratigraphy. 